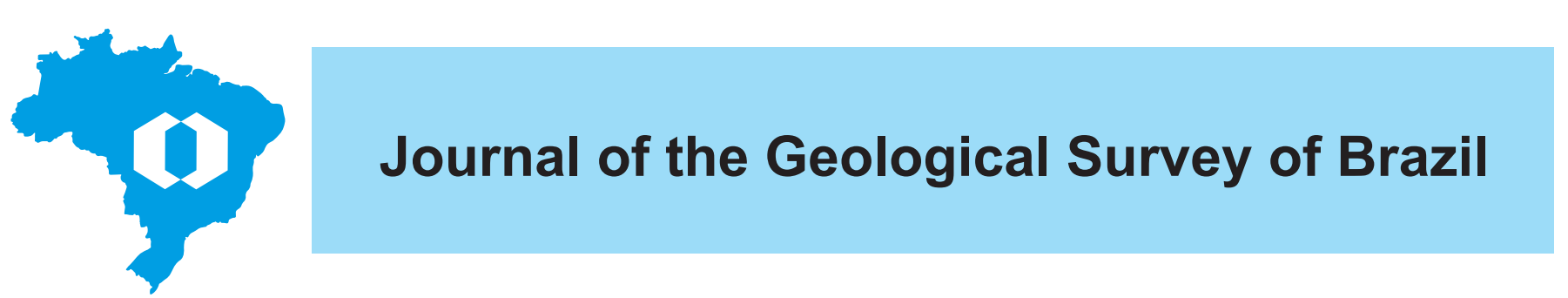

\title{
Mapping of superficial formations: a methodological proposal for systematic cartography of the Brazilian territory
}

\author{
Maria Angélica Barreto Ramos ${ }^{1^{*}(\mathbb{1})}$, Marcelo Eduardo Dantas² () , Maria Adelaide Mansini Maia², \\ Iris Celeste Nascimento Bandeira ${ }^{3}$, Jose Sidiney Barros ${ }^{4}$, Vivian Athaydes Canello Fernandes ${ }^{5}$, \\ Pedro Augusto dos Santos Pfaltzgraff ${ }^{2}$, Carlos Eduardo Osório Ferreira ${ }^{6}$ \\ ${ }^{1}$ Serviço Geológico do Brasil - CPRM, Avenida Ulysses Guimarães, 2862, Sussuarana - Centro Administrativo da Bahia, Salvador-BA, Brazil, CEP: 41213-000 \\ ${ }^{2}$ Serviço Geológico do Brasil - CPRM, Avenida Pasteur, 404 - Urca, Rio de Janeiro-RJ, Brazil, CEP: 22290-255 \\ ${ }^{3}$ Serviço Geológico do Brasil - CPRM, Avenida Dr. Freitas, 3645 - Bairro do Marco Belém-PA, Brazil, CEP: 66095-110 \\ ${ }^{4}$ Serviço Geológico do Brasil - CPRM, Rua Goiás, 312 - Sul, Teresina-PI, Brazil, CEP: 64001-620 \\ ${ }^{5}$ Serviço Geológico do Brasil - CPRM, Rua 148, 485 - Setor Marista, Goiânia-GO, Brazil, CEP: 74170-110 \\ ${ }^{6}$ In Memorian
}

\section{Abstract}

\begin{abstract}
We present a methodological proposal for the systematic mapping of superficial formations applicable on a national scale. The importance of such a proposition stems from the fact that a large part of the Brazilian territory is located in a humid or semi-humid tropical zone, where deeply weathered and sometimes tens of meters thick lateritized regolith mantles develop. The methodological approach consists of a geological-geomorphological-pedological compartmentalization of the terrains, together with elements of morphostratigraphic analysis and of the intrinsic properties of saprolites and soils. This approach, structured in a GIS environment, was applied in two different areas in Brazil: The Federal District and the São Luis island in the state of Maranhão, where the complex geodiversity of the regolith landscape stands out in both areas. The results highlight the diversity of horizons in the regolith profile, in addition to its anisotropy. The recognition of the complexity of these superficial formations is, therefore, of great importance for a more detailed analysis of various themes, such as for civil works; susceptibility to erosion and mass movements; potential for aquifer recharge; and mineral potential. Finally, the importance of the study of superficial formations is emphasized for the improvement of geological mapping and for the multi-thematic analysis of the physical environment applied to land management.
\end{abstract}

Article Information

Publication type: Review articles

Received 4 August 2020

Accepted 10 August 2020

Online pub. 15 December 2020

Editor: E. Klein

\section{Keywords:}

Superficial formations

Weathering,

Regolith landscape,

Geodiversity,

Land management

${ }^{*}$ Corresponding author

Maria Angélica B. Ramos

E-mail address: angelica.barreto@cprm.gov.br

\section{Introduction}

Processes of intense chemical weathering with generation of deep and complex saprolite and lateritic profiles are phenomena of great relevance for the understanding of the morphodynamic evolution of landscapes and the characterization of thick and diverse layers of alteration in humid and semi-humid tropical regions, as already studied by several authors in Brazil (Kotschoubey and Trunckenbrodt 1981; Costa 1991; Horbe et al. 1997; Martins et al. 2004, among others), Africa (Chardon et al. 2006; Grimaud et al. 2015; Arhin et al. 2015, among others) , and Australia (Pain and Ollier 1996; Gibson 1999; Butt et al. 2000; Craig 2001; Anand and Paine 2002, among others), in addition to classic worldwide studies (Millot 1983; Birkeland 1984; Thomas 1994; Butt and Zeegers 2015).
For conceptual reasons, it should be noted that, in lateritic profiles, the terms laterite and ferruginous crust must be differentiated. Latu sensu laterites cover the entire portion of the weathering mantle, predominantly composed of kaolinite, iron or aluminum oxides and hydroxides and resistant primary minerals, such as quartz and heavy minerals, such as rutile and zircon, with the formation of hardened plinthite nodules, arranged in pisolithic horizons above a terrigenous matrix. Lateritic crusts, or ferricretes, in turn, constitute a hardened horizon formed by iron or aluminum concretions (ferruginous or bauxite crusts), which are very resistant to weathering and erosion.

Brazil is a country of continental dimensions, largely subject to a humid tropical climate regime that promotes the development of a deep weathering mantle under conditions of intense chemical weathering, deep leaching of the regolith and formation of thick lateritic profiles with generation of ferruginous 
crusts (or ferricrete) close to the surface, associated with the development of Petroplinthic Plinthosols on geomorphological surfaces of prolonged tectonic stability. Remarkable exceptions are associated with the phyto-climatic regions of the semi-arid northeastern hinterland and the subtropical plateaus and pampas of southern Brazil. According to several authors (Schellmann 1983; Bardossy and Aleva 1990; Costa 1991, 2007; Freyssinet et al. 2005; Horbe and Costa 2005), laterite is conceptually defined as a geological product resulting from the intense tropical weathering throughout the Cenozoic, which can and should be considered a geological mapping unit through the identification and mapping of lateritic profiles, or lateritic formations. Since the 1960s, it has already been demonstrated the importance of studying superficial formations for understanding the evolutionary dynamics of the landscape (e.g., Ab'Saber 1962). In this context, the geomorphological literature has emphasized, in recent decades, the need for greater attention to the studies of weathering mantles to understand a model of landscape evolution applied to tropical humid and semi-humid regions (Büdel 1982; Millot 1983; Thomas 1994), with emphasis on relevant contributions by Brazilian geoscientists (Pinto 1987; Filizola and Boulet 1996; Horbe et al. 1997; Martins et al. 2004; Vitte 2005; Coltrinari 2011). After all, only in the intertropical zone the generation of deeply weathered regolith mantles more than tens of meters thick and, at times, lateritized, is observed (Fig. 1). Thus, the etchplain model recommended by Büdel (1982) proposes an analysis of a double planed surface that leads to the denudation of the relief: the first and classic, superficial, associated with the dissection promoted by the drainage network; and the second, deep, located at the interface between the saprolite and the bedrock.
Therefore, many geomorphological processes that occur in tropical humid areas cannot be understood using the classic models of erosion and denudation by the action of surface runoff elaborated by geoscientists who studied the various extratropical regions of the planet in areas of thin layers of weathering.

The intertropical world has its specificities and the geoscientists who study it need to be aware of this and address these peculiarities. In the meantime, and based on the evolution of knowledge recorded in the literature, two phenomena can be highlighted, in particular: a) the generation of laterite profiles as a notorious example of maximum weathering development in the tropics as they generate new-formed rocks - the ferruginous crusts - which are highly resistant to weathering and erosion (Figs. $2 a, 2 b$ and $2 \mathrm{c}$ ); b) the dismantling of the top of tabular surfaces by pseudo-karst phenomena of surface lowering promoted by etchplain processes based on the generation of thick regoliths with deep chemical weathering, geochemical alteration of minerals, mass loss, and percolation of finegrained particles and solutes by groundwater promoting the progressive dismantling of the tabular surface. Several studies emphasize the influence of pedogenic processes in the generation of closed depressions in hilltops or plateaus (Espíndola et al. 1981; Rosolen and Herpin 2008; Queiroz Neto 2010; Alves 2015). Some authors still emphasize a structural control in the generation of closed basins or depressions on such tabular surfaces (Filizola and Boulet 1996; Queiroz Neto 2001; Coelho Netto 2003; Ford and Williams 2007; Uagoda et al. 2011; Xavier and Coelho Netto 2014; Guareschi and Nummer 2014; Vital 2015) linking its occurrence to the intersection of joint sets.

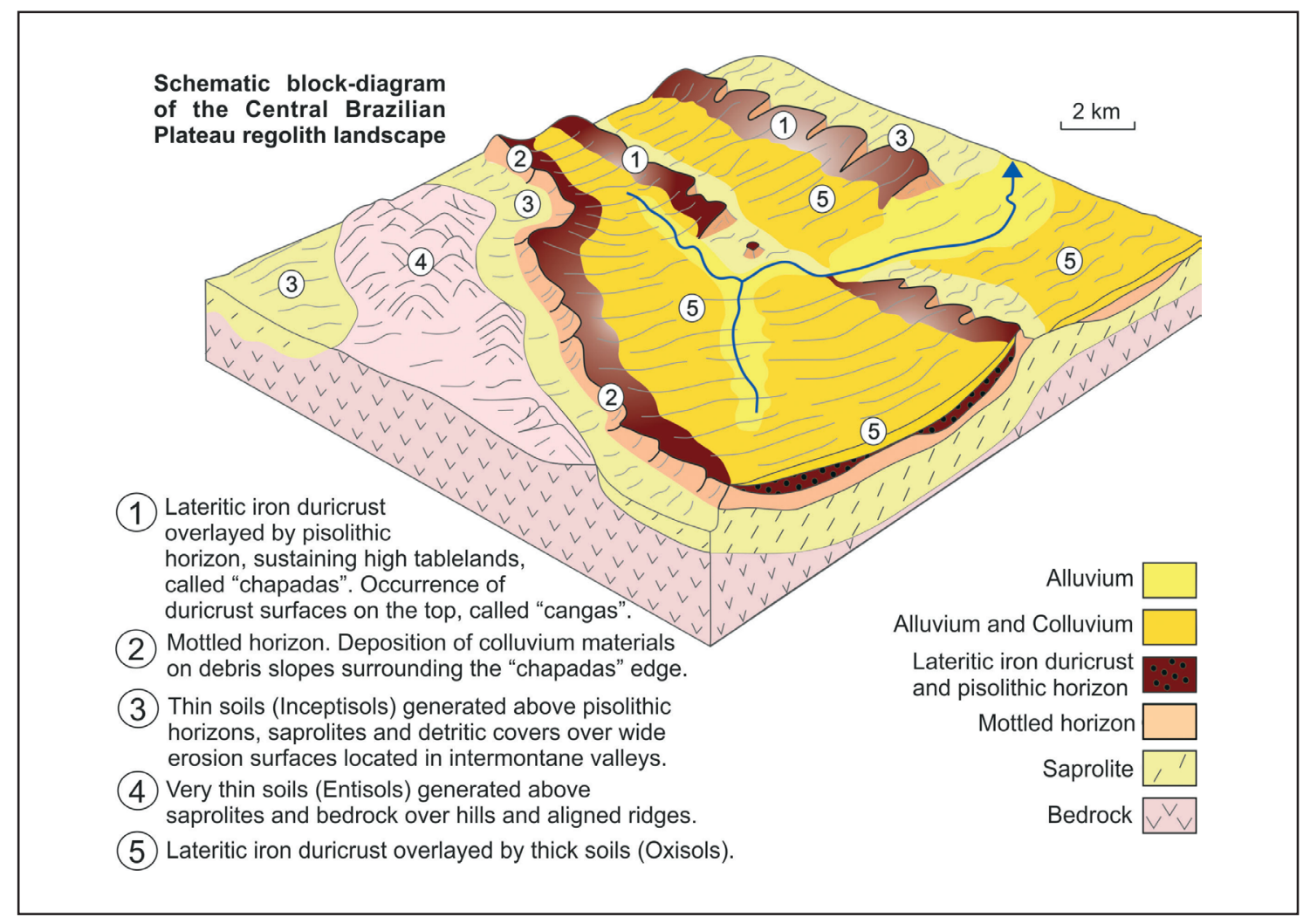

FIGURE 1. Schematic block diagram showing an intrinsic correlation between the geological substrate, the compartmentalization of the relief and the spatial distribution of the superficial formations and the weathering process. Modified from Anand and Paine (2002). 


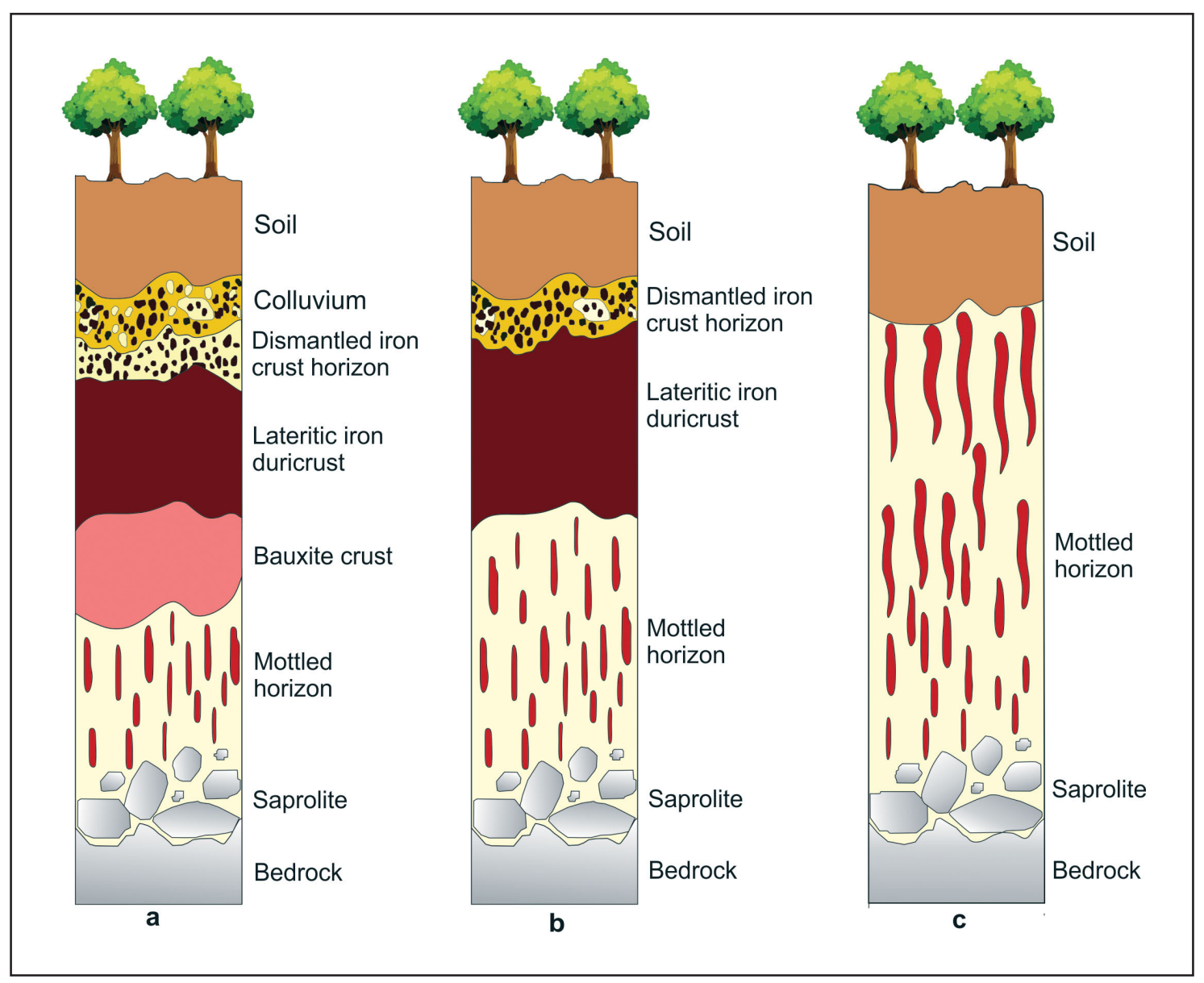

FIGURE 2. Possible types of weathering profiles (not to scale): a) Complete weathering profile (mature); b) Complete weathering profile (immature); c) Truncated or incomplete weathering profile (Horbe 2018, oral communication).

On the other hand, several authors in the past held a conceptual debate and consolidated some definitions that are currently entrenched in the geological and geomorphological literature, with the correct interpretation of each concept being important. In this sense, weathering is defined as a set of natural processes of decomposition or disintegration of rocks when exposed to surface conditions or physical and chemical alteration of rocks or minerals near or on the Earth surface. Weathering starts with the progressive disintegration and decomposition of the primary rock in situ forming a mixture of resistant primary and stable neoformed minerals in this new environment; the saprolite, in turn, refers to the in situ alteration profile (residual soil) of the weathering mantle. The regolith consists of a broader term, since it represents the entire surface layer of the Earth, which includes the set of horizons of the alteration profiles, sediments and soils formed by weathering, erosion, transport and deposition (Chiossi 1979; Ollier 1984; Birkeland 1984; Guerra and Cunha 1996; Scott and Pain 2008) (Figs. 3a and 3b).

The concept of regolith has a meaning very similar to that of unconsolidated covers or superficial formations, and can be specifically mapped, either through the morphostratigraphic analysis, the structural analysis of the pedological/saprolite cover, or the evaluation of terrain systems (Frye and Willman 1962; Dewolf 1983; Finlayson 1984; Moura and Mello 1991; Queiroz Neto 2001; Scislewski 2002; Espíndola 2013; Dantas et al. 2014).
The Geological Survey of Brazil - GSB/CPRM introduced this theme in the studies of Environmental Geology and Geodiversity, according to the approach of Scislewski (2002) and Ramos et al. (2018). As such, the concept of superficial formations encompasses the entire coverage of decomposed material overlying the bedrock, which may be of autochthonous, allochthonous, or secondary genesis (neoformed materials) (Fig. 4). It is frequently used by geographers and geologists and is widely applied by several professionals that work in the areas of Geomorphology, Engineering Geology, Pedology, Stratigraphy, and Quaternary studies, among others.

In this manner, superficial formations include materials generated in situ, resulting from the alteration of rocks or materials transported and deposited in other places by erosive agents or by gravitational movements, as well as neoformed materials (such as lateritic crusts, Belterra clays or calcretes). Deposits of anthropic origin, such as landfills, dumps, ore tailings piles, sambaqui, etc., are also considered as superficial formations,

Based on what was discussed earlier, this article opts to use the concept of superficial formations. It is noteworthy that the identification, mapping and analysis of superficial formations is of crucial importance for the integrated analysis of the physical environment applied to land management. The objective of this work, therefore, is to elaborate a proposal for cartography of superficial formations that allows for a systematic mapping of the Brazilian territory in semi-detailed to sub-regional scales $(1: 25,000$ to $1: 100,000)$. 

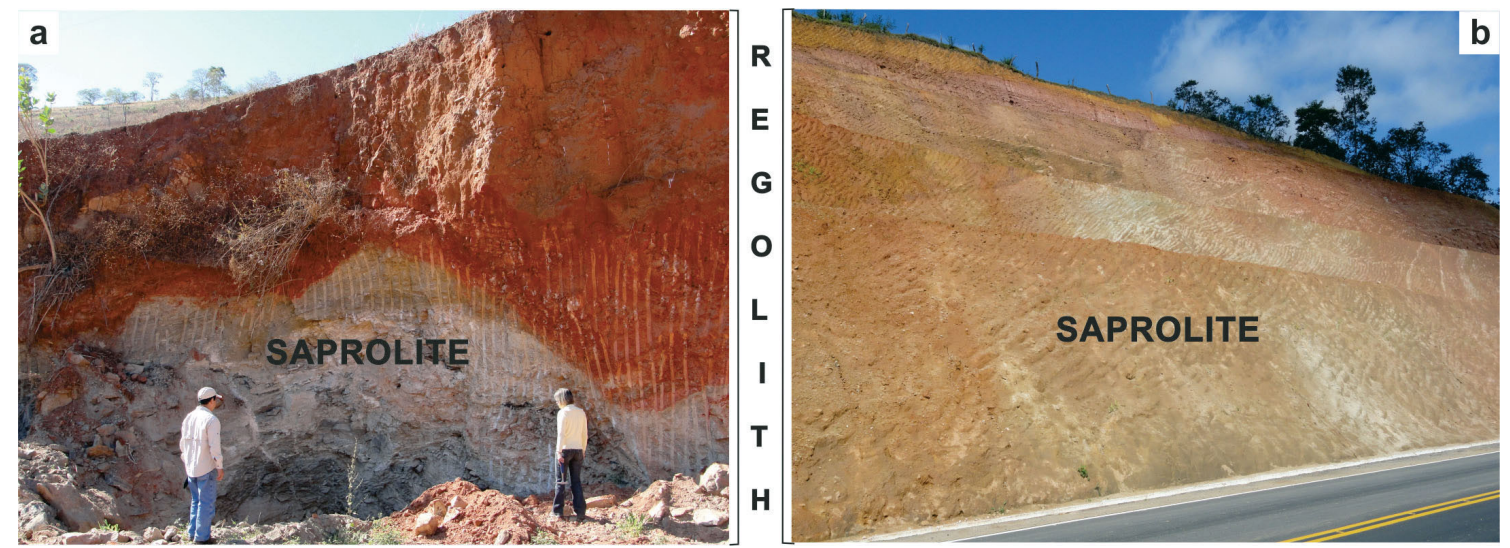

FIGURE 3. Examples of thick regolith showing distinction between the saprolite horizon at the base and the pedogenized soil at the top. a) Surroundings of Vila Nova do Bananal, and b) Afonso Claudio in the state of Espírito Santo.

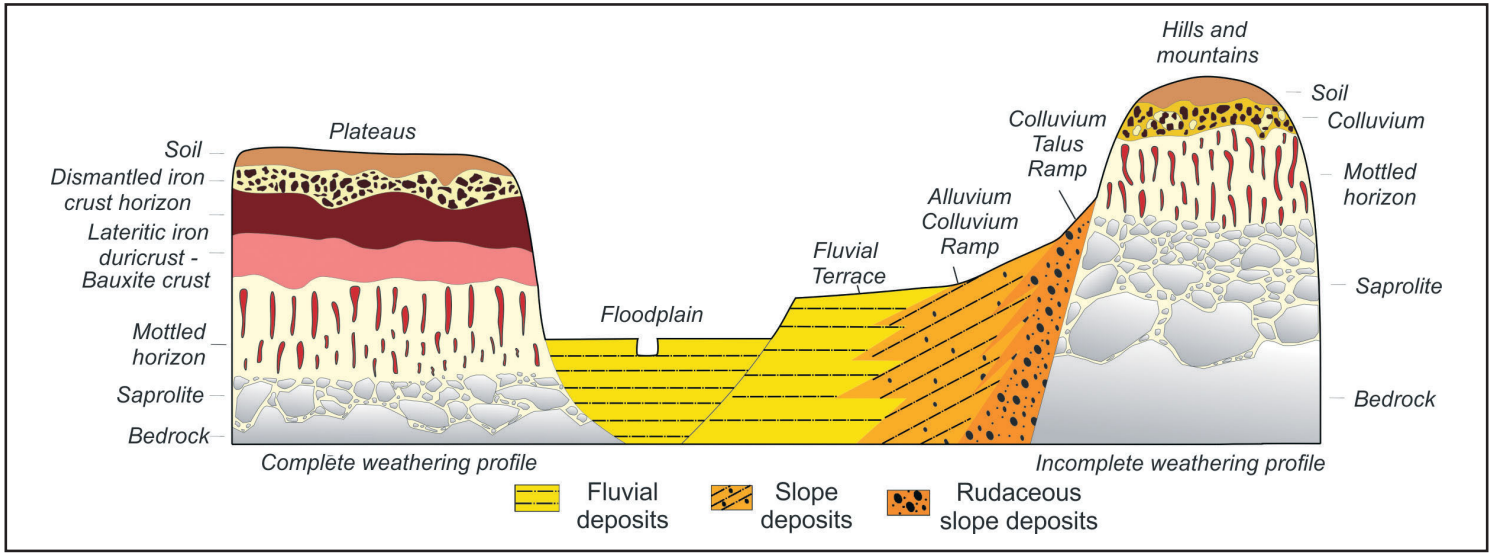

FIGURE 4. Schematic distribution (not to scale) of the different Quaternary depositional environments and their related superficial formations/regolith.

\section{Methodology}

For the elaboration of the systematic cartography of the superficial formations, evaluation methods already described in the literature were incorporated, coupled with the CPRM systematic work, with emphasis on the evaluation of terrain systems, combined with elements of morphostratigraphic analysis and the intrinsic properties of saprolites and soils, all structured for a Geographic Information System - GSI.

From an integrated analysis of the physical environment with an emphasis on the compartmentalization of relief and geological materials, including the saprolites and their mottled horizons, overlapping or not with lateritic crusts, and the autochthonous/allochthonous residual covers, and the soils, the superficial formations can be preliminarily interpreted based on several remote sensors.

The refinement of the mapping and the delimitation of the superficial formations units were made based on the field survey aiming at the adjustment of the limits between each unit with emphasis on the identification and analysis of the structure of the regolith mantle and later collection of data and samples.

The type of process involved in the removal of the autochthonous regolith and deposition in a lower topographic position is of fundamental importance for the understanding of allochthonous superficial formations. In this context, the predominance of gravitational processes (mass movements latu sensu) tends to generate deposits of talus, colluvium, and debris slopes. On the other hand, the greater influence of hydro-erosive processes (laminar erosion, ravines and gullies) tend to produce alluvial fans, alluvial-colluvial ramps, and fluvial plains.

The mapping of superficial formations is outlined based on a library of regolith patterns (Table 1) that will structure all maps of superficial formations prepared by CPRM and that can be correlated to the lithostratigraphic units of its base belonging to its corporative database GeoSGB (http://geosgb.cprm.gov. $\mathrm{br} /$ ). The soil taxonomy used here follows IUSS Working Group WRB (2015) classification, which is the equivalent systematics for the Brazilian Embrapa classification (Santos et al. 2018).

As the weathering process is considered in the cartography of superficial formation units, in practice it is necessary to have a composition of the regolith terminology that reflects the weathering profile, and that is often only represented on the surface by the soil. The scale of the work, and the possibility of describing profiles in the field with sampling are fundamental for a better delimitation of horizons.

It is necessary to keep in mind that the soils are inserted in the definition of the term regolith. However, in the proposed methodology they do not name the regolith unit, but can be included in the information of the Regolith Code (Cod_REG), as well as in the database attributes (name of soil up to the second order and thickness), and in the legend of the map of superficial formations. 
TABLE 1 - Library of terms for description of the regolith

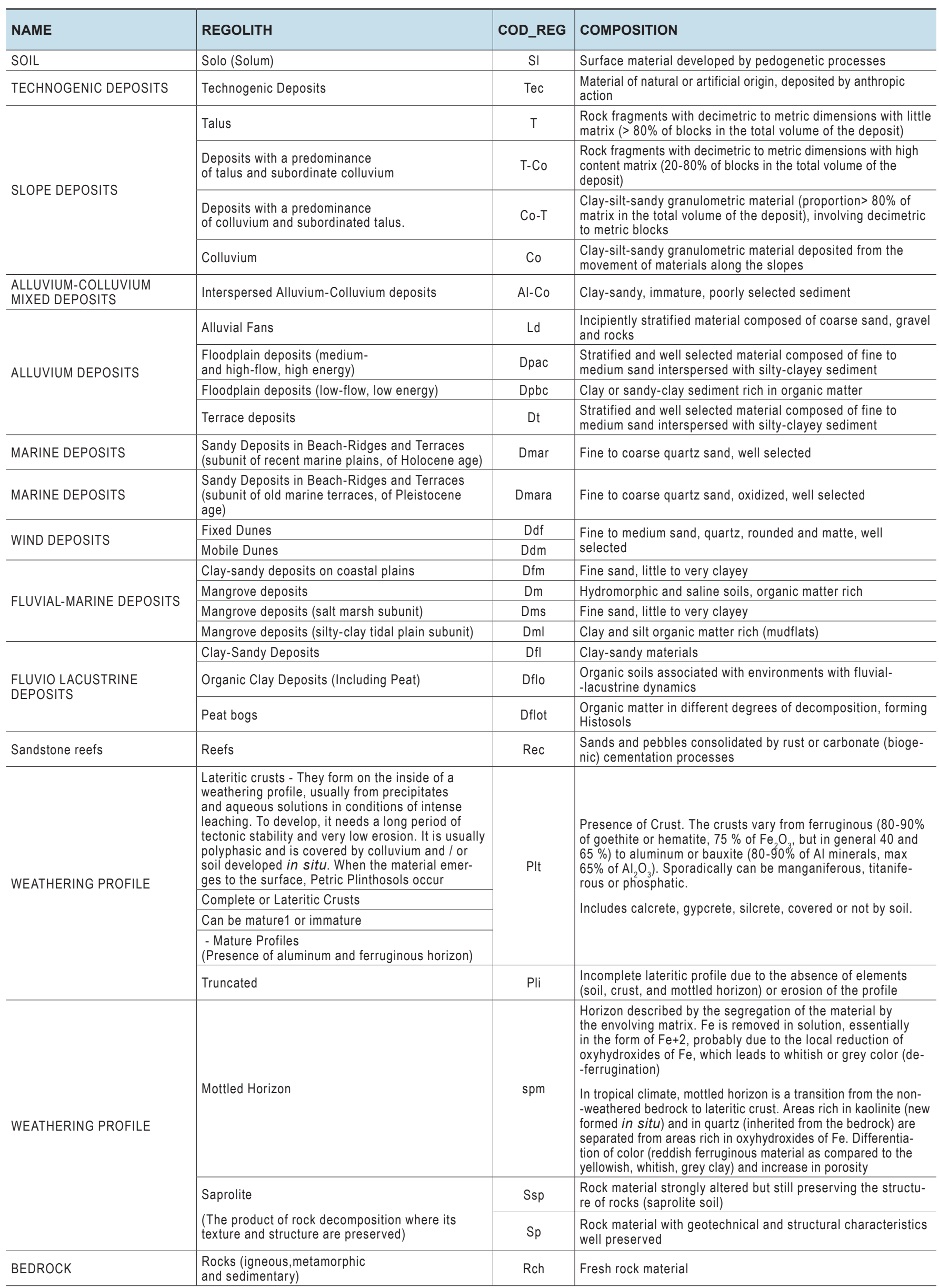




\section{Results}

As case studies, we present the results obtained with the proposed methodology for the cartography of superficial formations and their regolith mantle in São Luis Island in the state of Maranhão (Bandeira et al. 2018), and in the Federal District (Fernandes et al. 2018) as a part of the CPRM Geodiversity Project are.

\subsection{São Luís Island in the State of Maranhão}

\subsubsection{Geological Evolution}

The São Luís Island is located in the north of the State of Maranhão, with an area of approximately $1412 \mathrm{~km}^{2}$ (Fig. 5). Geomorphologically, the island is characterized as a topographic high amid the emerged lands of the Maranhense Gulf (Dantas et al. 2013), and is positioned geologically in the Basin of Aborted Rift of São Luís and Ilha Nova, whose origin is associated with a system of grabens developed on the São Luís Craton fragment, during the opening of the Atlantic Ocean, in the Early Cretaceous (Azevedo 1986; Szatmari et al. 1987; Aranha et al. 1990; Góes and Rosseti 2001; Vasquez et al. 2012). On this cratonic fragment, a pre-rift sequence, of Aptian age, was deposited, composed of red sandstones intercalated with argillites of the Grajaú Formation, which formed in transitional fluvial setting, and intercalations of lacustrine and marine shales, limestones and evaporites of the Codó Formation (Soares Junior et al. 2008). In a second extensional event, a rift sequence was deposited during the Albian, represented by coastal sandstones, siltstones, conglomerates, and shales associated with a deltaic fluvial system with marine inflows from the Itapecuru Group (Lima et al. 1994).
According to Rossetti (1996, 1997, 2001), and Rossetti and Truckenbrodt (1997), this sedimentary sequence is divided into three formations: Undifferentiated Unit (Albian); sandstone, claystone, and subordinate limestone and conglomerates of the Alcântara Formation (Albian-Cenomanian); and fine- to very fine-grained and well-sorted kaolin-bearing sandstones, having white or pinkish to yellowish colors, white, gray to violet colored argillite and intraformational conglomerates, with clay clasts and sandy matrix of the Cujupe Formation (UpperPaleogenic Cretaceous).

The Alcântara and Cujupe formations, on the São Luís Island, underwent weathering under a humid tropical climate, with the generation of an immature lateritic profile subdivided into (a) lateritic profile with preserved lateritic crusts, changing to soil, or covered by sediments of the Post-Barreiras Formation, and (b) lateritic profile truncated by erosivedepositional processes, without preserved crust, covered by pisolithes. However, it cannot be ignored that part of these concretions were generated in situ, from the degradation of non-remobilized ferruginous crusts, as postulated by Tardy and Nahon (1985).

The rise of the sea level in the Holocene led to the erosion of the Itapecuru Group deposits, forming cliffs, as well as beach deposits, dune fields, and mangroves (Souza Filho and El-Robrini 1997).

\subsubsection{Mapping of superficial formations}

The mapping of the island of São Luís at the 1: 50,000 scale identified ten regolith units (Fig. 5), that include lateritic crusts and truncated lateritic crusts (which represent the immature lateritic weathering profiles in the region); sandy deposits on beach ridges and terraces (both ancient and

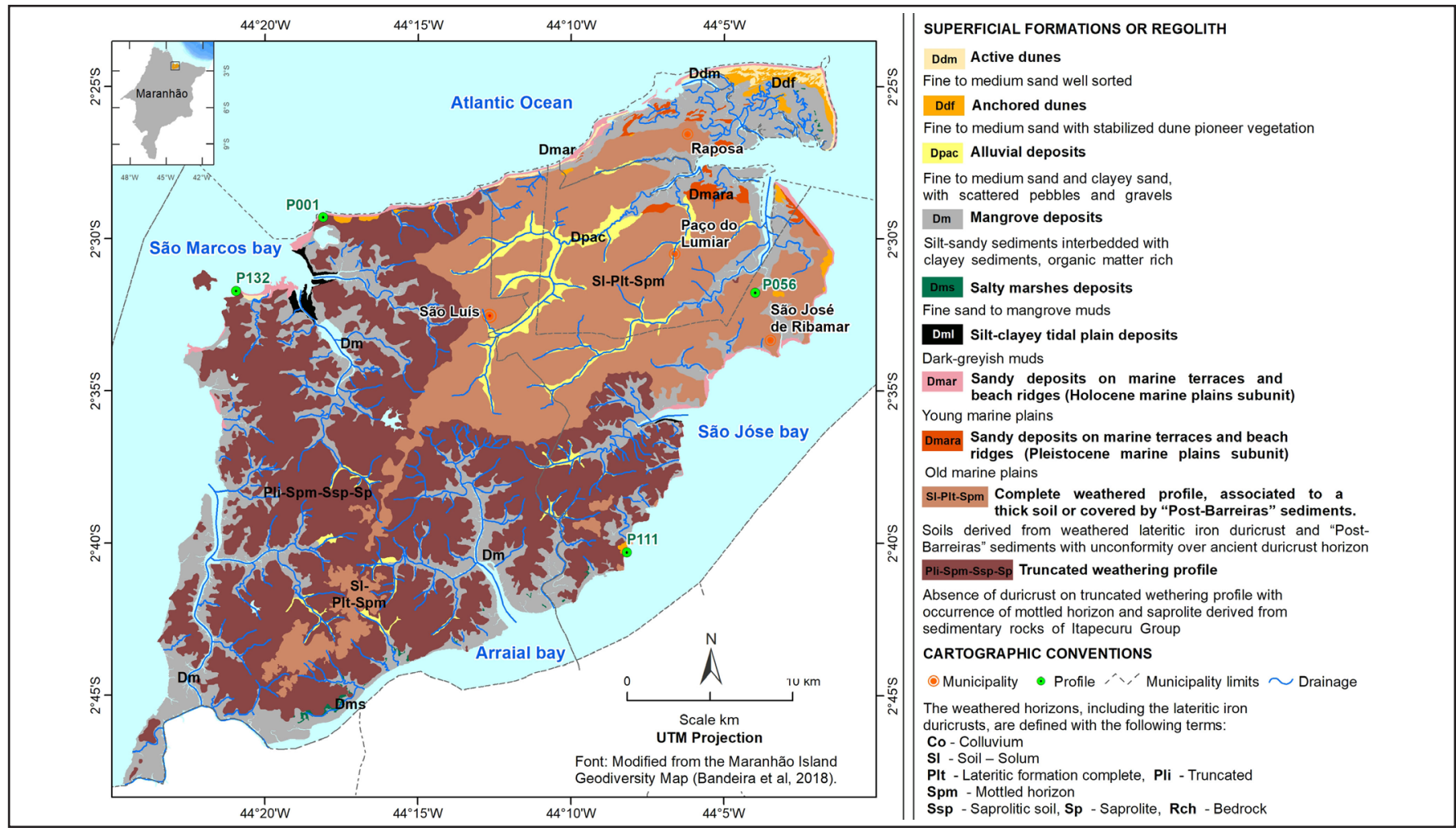

FIGURE 5. São Luís Island superficial formations map 
recent); mangrove deposits (covering both mangroves and salt marshes); mobile and fixed dunes; and floodplain deposits (low-flow, low energy).

\subsubsection{Mobile dunes - Ddm}

Mobile dunes are deposits that cover a small area of $0.65 \%$ of the island, located close to the beach line. They are of marine origin, subsequently remobilized by the wind, and composed of fine, well-selected sand, with no vegetation (Fig. 6a).

\subsubsection{Fixed dunes - Ddf}

The fixed dunes cover $0.78 \%$ of the island and occur at the rear of or interspersed with mobile dunes and present incipient pedogenic processes with the development of Arenosols, resulting in the fixation of a pioneer plant cover (grasses and sparse shrubs), which prevents or mitigates wind mobilization. The dunes are formed by whitish, fine- to medium-grained and well-selected quartzose sands. They often contain levels of heavy minerals, mainly ilmenite. Medium- to large-scale cross stratifications, as well as eolian ripple marks (Figs. 6b, 6c), and form thin, sand-rich soils, such as Arenosols.

\subsubsection{Alluvial deposits - Dpac}

The alluvial deposits are located along the banks of rivers and cover about $3.65 \%$ of the area of the São Luís island. The deposits (Fig. 6d) are associated with plains, constituted predominantly of fine to medium sand and silty-clayey sediments, with scattered pebbles and granules.

\subsubsection{Mangrove deposits} (salt marshes subunit) - Dms

The salt marshes subunit represents $0.14 \%$ of the island's area and is composed of fine sand and silty-clayey sediment from the mangrove environment (Fig. 6e), with high salinity due to tidal fluctuations, especially spring tides. In the period of low rainfall, mainly from July to November, hypersaline plains are formed due to the precipitation of salt resulting from the evaporation of water that penetrates these plains, sporadically, during the spring tides (Fig. 6f). They are associated with the relief of a fluvial-marine plain and generally lack vegetation or, when existing, the vegetation is thin. The deposits are identified by the local scientific community as salt marshes (apicuns).

\subsubsection{Mangrove deposits} (silt-clay tidal plain subunit) - Dml

Also called mudflats, the silt-clay tidal plain subunit comprises muddy, dark gray pelites, exposed at low tide (Figs. $6 \mathrm{~g}, 6 \mathrm{~h}$ ), which cover $0.31 \%$ of the São Luís island. They are composed of hydromorphic and saline soils.

\subsubsection{Mangrove deposits - Dm}

The mangrove deposits constitute $23.24 \%$ of the area, and represent thin deposits composed of fine sediments (clay, silt, and fine sand), dark gray in color, rich in organic matter, and transported by river waters, which under the influence of the tide, promote the flocculation of clays and deposition under low energy conditions, in relief of the fluvial-marine plain. They generate mangrove soils in an unusual environment of periodically flooded land, with intense biological activity and high salinity (Vidal-Torrado and Ferreira 2017) (Fig.6i).

\subsubsection{Sandy marine deposits in beach ridges and terra-} ces (recent marine plains subunit - Holocene age) - Dmar

The recent marine plain deposits cover about $1.34 \%$ of the island and correspond to the recent (Holocene) beach ridges deposits (Figs. 6j). They consist of fine sands associated with the relief of the marine plain, with the development of hydromorphic Arenosols.

\subsubsection{Sandy marine deposits in beach ridges and} terraces (ancient marine terraces subunit - Pleistocene age) - Dmara

The ancient marine terraces occupy $0.76 \%$ of the area and located in the innermost portions of the island. They are composed of fine, whitish, unconsolidated sands, partly covered by restinga vegetation, associated with old beach areas (Figs. 6k, 6l). These deposits comprise Podzol and Arenosol, and represent an old limit of the coast line, when the sea level was higher.

\subsubsection{Complete weathering profile, associated with thick soil or covered by Post-Barreiras sediments - SI- PIt-Spm}

The complete weathering profile is distributed in $29 \%$ of the island, and is composed of two types of cover: thick soil formed by alteration/degradation of lateritic crust (Fig. 7a), and allochthonous sediments from the Post-Barreiras Formation (Fig. 7b). These materials support a relief of tables, with flat to gently wavy tops, altitudes between 45 and $60 \mathrm{~m}$ and low amplitudes and slopes.

The soils vary from 1 to $8 \mathrm{~m}$ in thickness, and are characterized by sand, sand-silt-clay, and silt-sand showing yellow-reddish colors. They are associated with the ferruginous crust (Fig. 7c), arising from the alteration of rocks in the Itapecuru Group, forming red-yellow Acrisols (Fig. 14d) and red-yellow Ferralsols.

The Pleistocene allochthonous sediments of the PostBarreiras Formation are characterized by sand and sand-silt sediments having yellowish-white and/or ocher color (Fig. 8a). They are usually massive, fine- to medium-grained, with rounded to sub-rounded grains, generally pedogenized and forming Arenosol, set discordantly over the concretion horizon (Fig. 8b).

\subsubsection{Truncated weathering profile - Pli-Spm-Ssp-Sp}

The truncated weathering unit covers $40 \%$ of São Luís island, and is formed by intercalations of sand and silt-claysand layers with laminae of clay and silt of variegated colors (yellow, purple, red, and whitish), intensely weathered, forming a truncated immature lateritic profile (Figs. 9a, 9b), with no preserved lateritic crust. From the base to the top, an highly altered sedimentary saprolite is observed, with preservation of sedimentary structures, such as channeled cross-stratification 

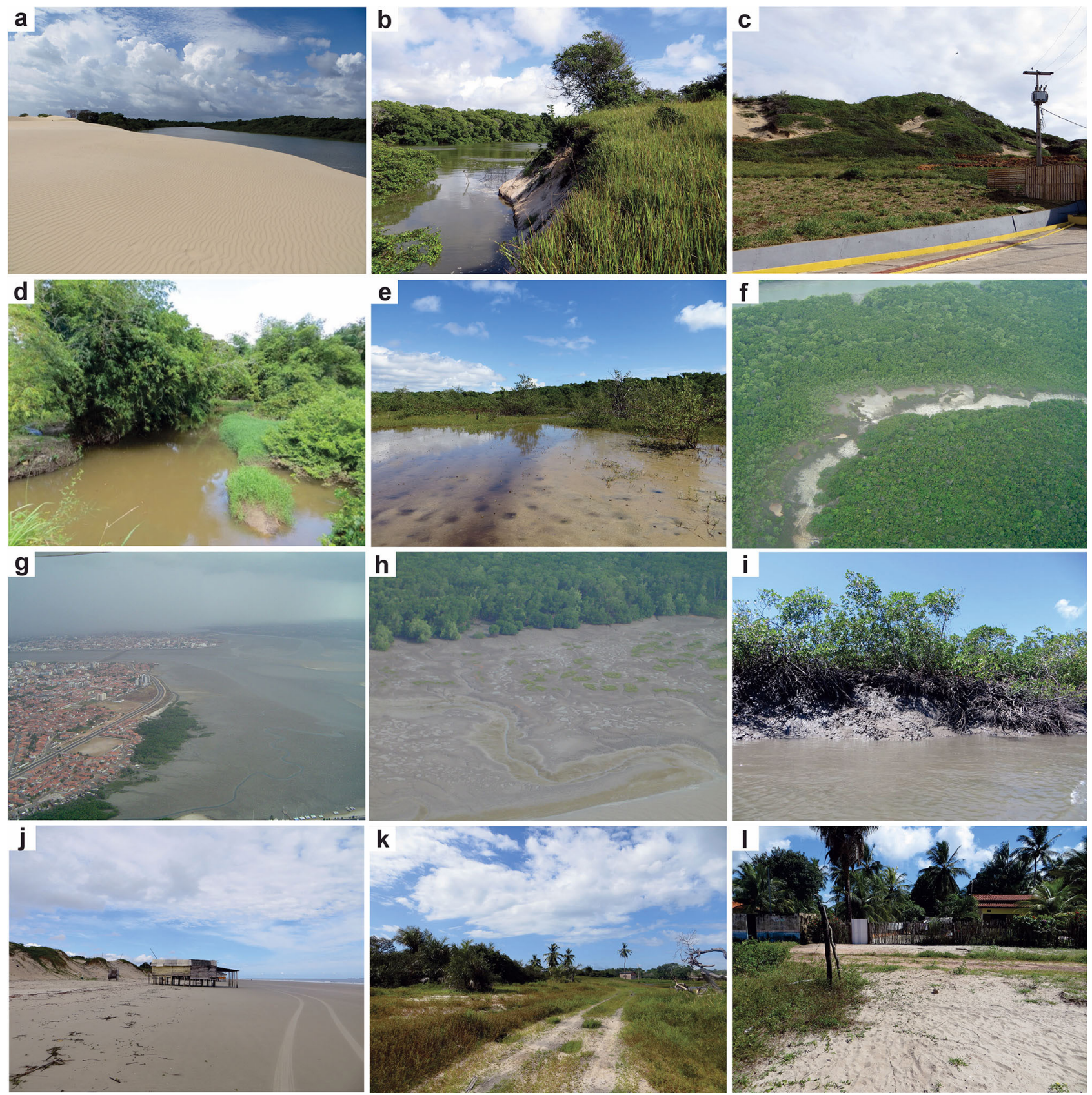

FIGURE 6. a) Mobile dunes without vegetation - Carimã Environmental Protection Area, municipality of Raposa, State of Maranhão. b) Paleo-dunes between tidal channels, composed of white, well-selected fine to medium sand, covered by cerrado vegetation: arboreal, shrub, herbaceous. Curupu Island, Munjijaia River, Raposa- state of Maranhão. c) Dunes fixed by vegetation, associated with a relief of dune fields, municipality of São Luís - state of Maranhão. d) Fluvial plain of the Paciência river - Highway MA-204, municipality of Paço do Lumiar - state of Maranhão. e) Area of saline fields covered by tidal water in the rainy season. Curupu Island, municipality of Raposa-Maranhão. f) Aerial photograph in the dry season, showing in white the area of occurrence of the saline fields, close to Arraial Bay (Teixeira 2006). g) Aerial photograph showing the silt-clay tidal plain located in the northwest portion of the São Luís island (Teixeira 2006). h) Silt-clay tidal plain located in the eastern portion of São Luís Island, between the Jeniparana river and São José Bay (Teixeira 2006). i) Mangrove deposit covered by red mangrove vegetation, and bordered by tidal channels. Curupu Island, municipality of Raposa - state of Maranhão. j) Coastal deposits. Araçagy Beach, municipality of São José do Ribamar-Maranhão. k) Deposits of ancient beach ridges forming sandy soils (Arenosol) overlapped by sandy beach-ridge vegetation (restinga), associated with relief of the marine plain. Praia do Cocal, municipality of Raposa - Maranhão. I) Urbanized area of Paço do Lumiar associated with beach ridges and characterized by a flat morphology with association of sandy soils. Paço do Lumiar-Maranhão. 

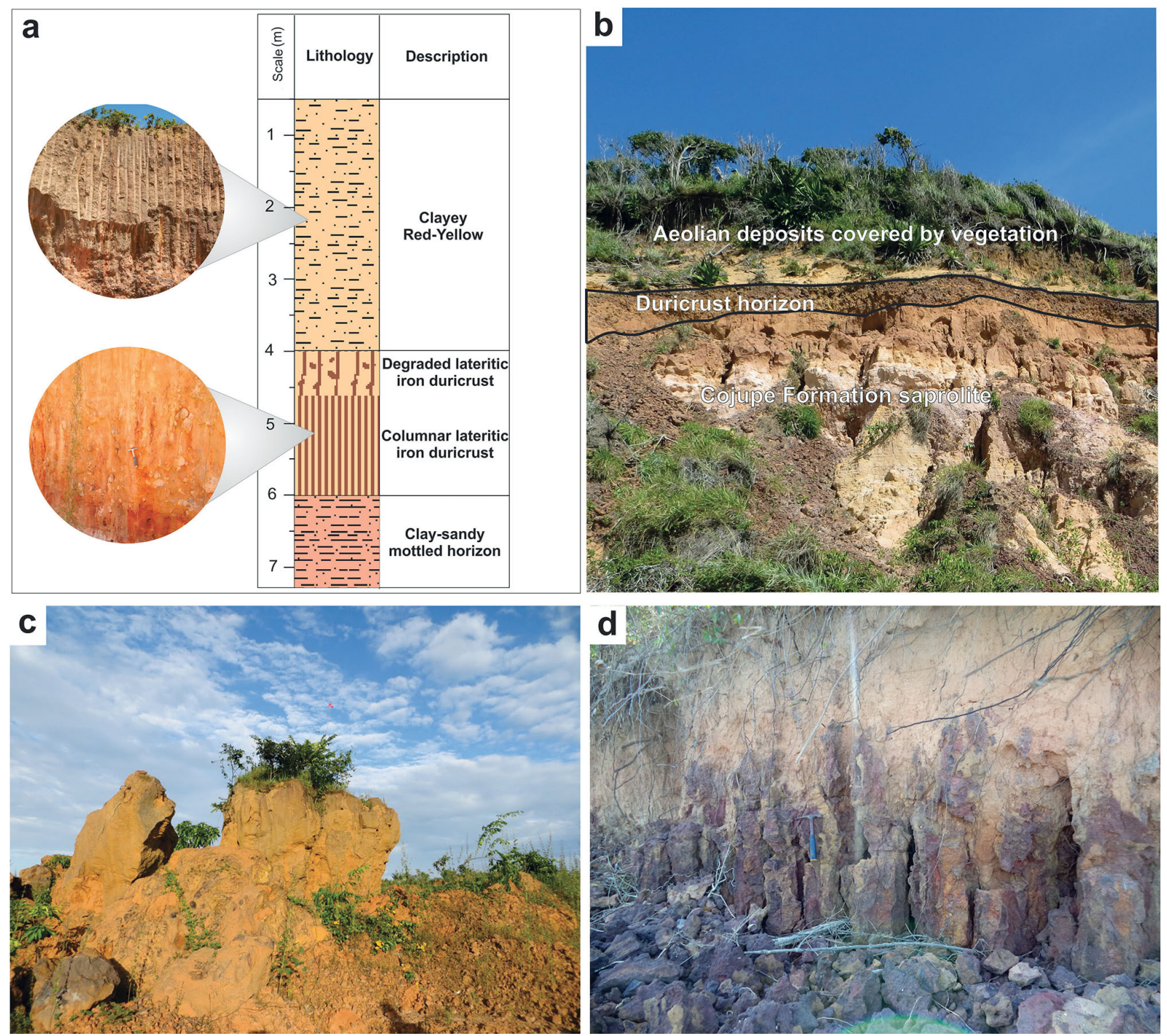

FIGURE 7. Aspects of the lateritic units in the municipality of São Jose do Ribamar, state of Maranhão. a) Profile 56 - Lateritic profile: from the base to the top the mottled horizon graded to lateritic crust, which in turn forms the Acrisol. (Bandeira et al. 2018). b) Profile 111 - 21m high cliff composed at the base of a thick package of fine sandstone, grading to a layer of sandstone with intercalations of claystone, which due to weathering, originated a ferruginous concretionary horizon, covered by wind sediments. c) Lateritic crust with columnar structure, associated with ferruginous sandstones. d) Lateritic crust with well-preserved columnar structure, with channels filled with sand-clay material, grading to an Acrisol.
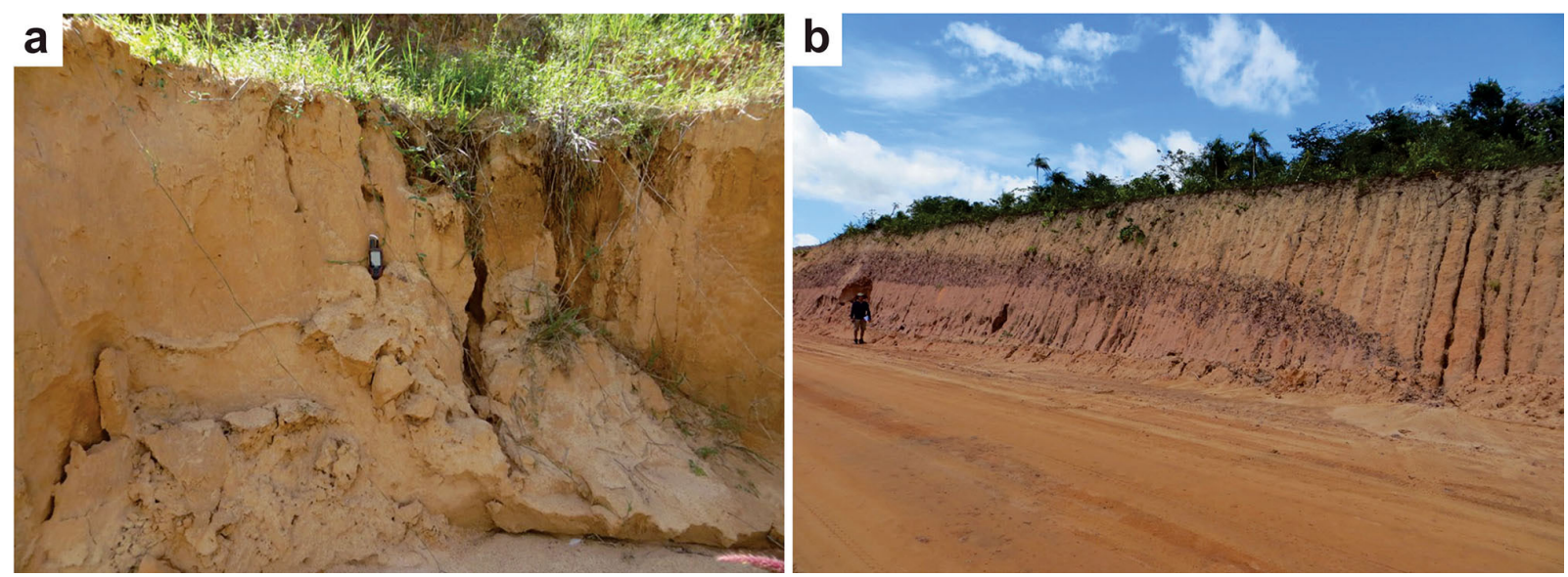

FIGURE 8. a) Erosive edge of table relief, supported by predominantly sandy, quartzose soil (Arenosol), municipality of Raposa, state of Maranhão. b) $4 \mathrm{~m}$-high profile made up of fine, poorly sorted massive red sandstone, grading to a ferruginous concretionary level in the middle of a reddish sand-silt matrix of 0.8 to $1.5 \mathrm{~m}$ in thickness, covered by $1.20 \mathrm{~m}$ - thick pedogenized sand-silt-clay sediment. Mateus distribution center, São Luís, Maranhão State. 
and heterolithic bedding (Fig. 9c), with a mild degree of resistance, grading towards a mottled horizon (Fig. 9d) very mild, superimposed by a concretionary horizon (ferruginous fragment/concretions smaller than $30 \mathrm{~cm}$ set in the sand-clay matrix) (Fig. 9e) and sometimes by dismantled lateritic crust (ferruginous fragments larger than $30 \mathrm{~cm}$ ). These layers are always associated with Petroplhintic Plinthosols and shallow concretionary red-yellow Acrisol and petroplinthic red-yellow Ferralsol, covered by scattered lateritic gravel (Fig. 9f). This material supports a relief of dissected tables and in small areas, tables with flat tops.

\subsection{Federal District}

\subsubsection{Geological Evolution}

The Federal District area, with $5,780 \mathrm{~km} 2$, in the Midwestern Region of Brazil (Fig. 10), consists of low-grade metasedimentary rocks included in the Paranoá, Canastra, and Bambuí groups, which are part of the Brasília Belt, related to the Neoproterozoic. These units are covered by Cenozoic laterite crusts, alluvial deposits, and unconsolidated colluvium and talus deposits (Faria 1995; Faria and Dardenne 1995; Barbosa et al. 1970).

In morphological terms, the region is formed predominantly by elevated plateaus that constitute the surfaces higher than the adjacent lands and, invariably, are positioned at elevations above 1,000 meters of altitude. They represent little dissected terrains, with tabular forms or very wide hills. In this context, the drainage systems are poorly carved and the river plains are narrow, restricted, or confined to closed valleys.

The depressions surrounding the high valleys of the Maranhão and São Bartolomeu rivers, in turn, are characterized by a strongly dissected relief due to the deepening of the main rivers at elevations below 800 meters. Thus, such lands were generated by denudation processes, and sculpted predominantly in metasedimentary rocks, but also on crystalline rocks. In the breaking of the plateau relief, scarps, and structural steps occur, and are associated with the metapelitic rocks and metalimestones of the Paranoá Group.

The geological context of the territory of the Federal District is based on the mapping of the proposed EcologicalEconomic Zoning of the Integrated Development Region of the Federal District and Surroundings (RIDE Phase 1, CPRM 2003), which was validated in the field at the scale of the project Geodiversity of DF 1:100,000 (Fernandes et al. 2018).

\subsubsection{Superficial formations}

During the geodiversity mapping of the Federal District (Fernandes et al. 2018), the superficial formations of the area were surveyed and thirteen different formations were described (Fig. 10), which are detailed below.

\subsubsection{Alluvial deposits (Dpac)}

The alluvial deposits are arranged on the alluvial plains, where unconsolidated sand and sand-clay materials are deposited, with thickness varying from 50 to $100 \mathrm{~cm}$, and classified as Fluvisols. The sediments occur in the wider of the drainage basins, in a floodplain environment, mainly in the hydrographic basins of the São Bartolomeu and Rio Preto rivers (Figs. 11a, 11b).

\subsubsection{Colluvium-alluvial deposits (Al-Co)}

The colluvium-alluvial deposits are restricted to reliefs of slopes, in terrains with slopes varying between 5 and 10 degrees, where Fluvisols with thickness varying from 50 to $100 \mathrm{~cm}$ are observed. They are unconsolidated deposits of mixed origin, partly derived from the dynamics of slopes, and partly alluvial, which occur interfinger in flat areas or in as very smooth ramps, at the limit between the bottom of the slopes and the drainages (Fig. 11c).

\subsubsection{Colluvial deposits (Co-T)}

Colluvial deposits occur in colluvial ramps to talus deposits reliefs, where the slope varies from 10 to 25 degrees, and where Cambisols with thickness varying from 50 to $100 \mathrm{~cm}$ are found. The materials derived from gravitational transport, which are deposited at the base of the slopes (structural steps) of the Central Plateau, include a mixture of soils of varying grain-size, and may have blocks and boulders of different sizes (Figs. 11d, 11e).

\subsubsection{Clay-sandy deposits (Dfl)}

The clay-sandy deposits are predominantly clay deposits originating from fluvio-lacustrine sedimentation, which occur exclusively in fluvio-lacustrine plains (marshes) (Fig. 11f). They are composed of constantly flooded unconsolidated sand, sand-clay, and peat-rich sediments, which occupy mainly the narrow plains of the tributaries of the upper Preto river, presenting Gleysols. with a maximum thickness of 50 $\mathrm{cm}$. Such closed depressions in the Federal District plateau can be generated by lowering and vertical degradation of geomorphological surfaces in carbonate rocks of the Bambui group, under strong structural control, as observed by Schrage and Uagoda (2017).

\subsubsection{Complete lateritic formations (PIt)}

The complete lateritic formations comprise the complete weathering profile of the soil with the presence of a lateritic crust (Fig. 12), which occurs exclusively in the plateaus with a slope varying from 2 to 5 degrees. The profiles were derived from the tropical or paleotropical weathering of any type of rock exposed to the surface, or close to it, and can evolve to the formation of lateritic crust. Lateritic crusts usually occur at the highest elevations and support plateaus tops and other higher landform.

\subsubsection{Truncated incomplete lateritic formations (Pli)}

The truncated lateritic formations (Pli), in general, occur in the plateaus where the slope is between 0 and 5 degrees, sometimes appearing in reliefs of flattened surfaces degraded to low hills, with terrains varying from 3 to 20 degrees of slope, and there is dominance of Petrophintic Plinthosols or Ferralsols (Fig. 13), with thickness ranging from 10 to 50 meters. 


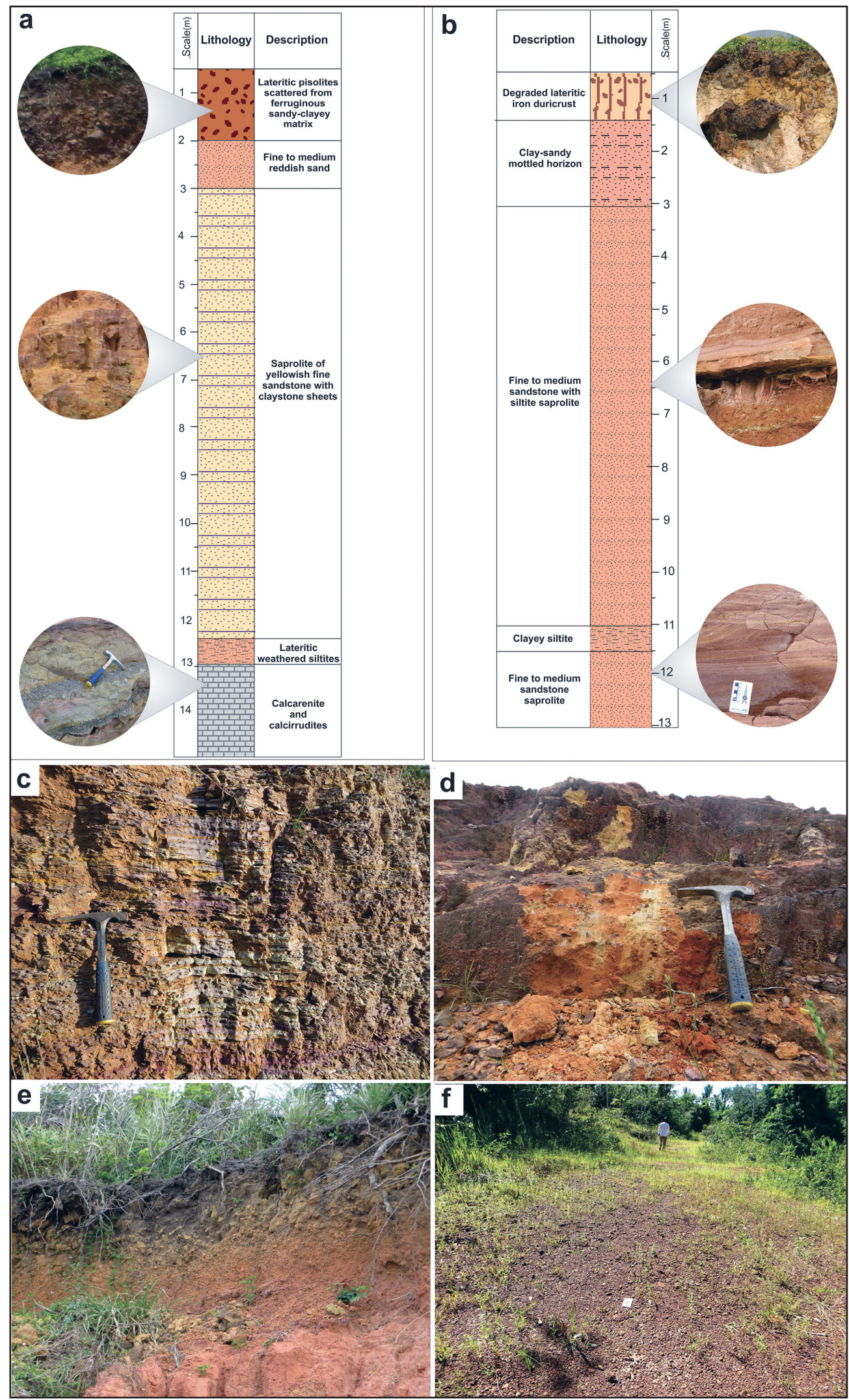

FIGURE 9. a) Profile 01 - Incomplete lateritic profile: sand-clay saprolite, mottled horizon grading towards a concretionary horizon. Cliff on Ponta da Areia beach, São Luís city -Maranhão state (Bandeira et al. 2018). b) Profile 132 - Sandstone with sedimentary structures (crossed, swaley, hummocky) and heterolithic layers grading towards a mottled horizon overlaid by dismantled lateritic crust, forming boulders and ferruginous blocks. Cliff in Praia do Amor, São Luís-Maranhão (Bandeira et al. 2018). c) Sedimentary saprolite composed of heterolithic bedding, with intercalations of reddish sandstones and pelites from the Itapecuru Group. Olho d'Água beach, São Luís-Maranhão. d) Itapecuru Group mottled horizon. Via da Marinha do Brasil - Ponta da Espera Road, São Luís-Maranhão. e) Ferruginous concretionary horizon, approximately 1 m-thick, derived from reddish yellow sand-silt material with clay lenses, fragmented and lateritized. Aribual Beach - Municipality of São José do Ribamar -Maranhão state. f) Flat terrain covered by dismantled lateritic concretions, with sizes ranging from 2 to $25 \mathrm{~cm}$ (granules and pebbles) of iron composition, with alteration minerals such as hematite and goethite. 


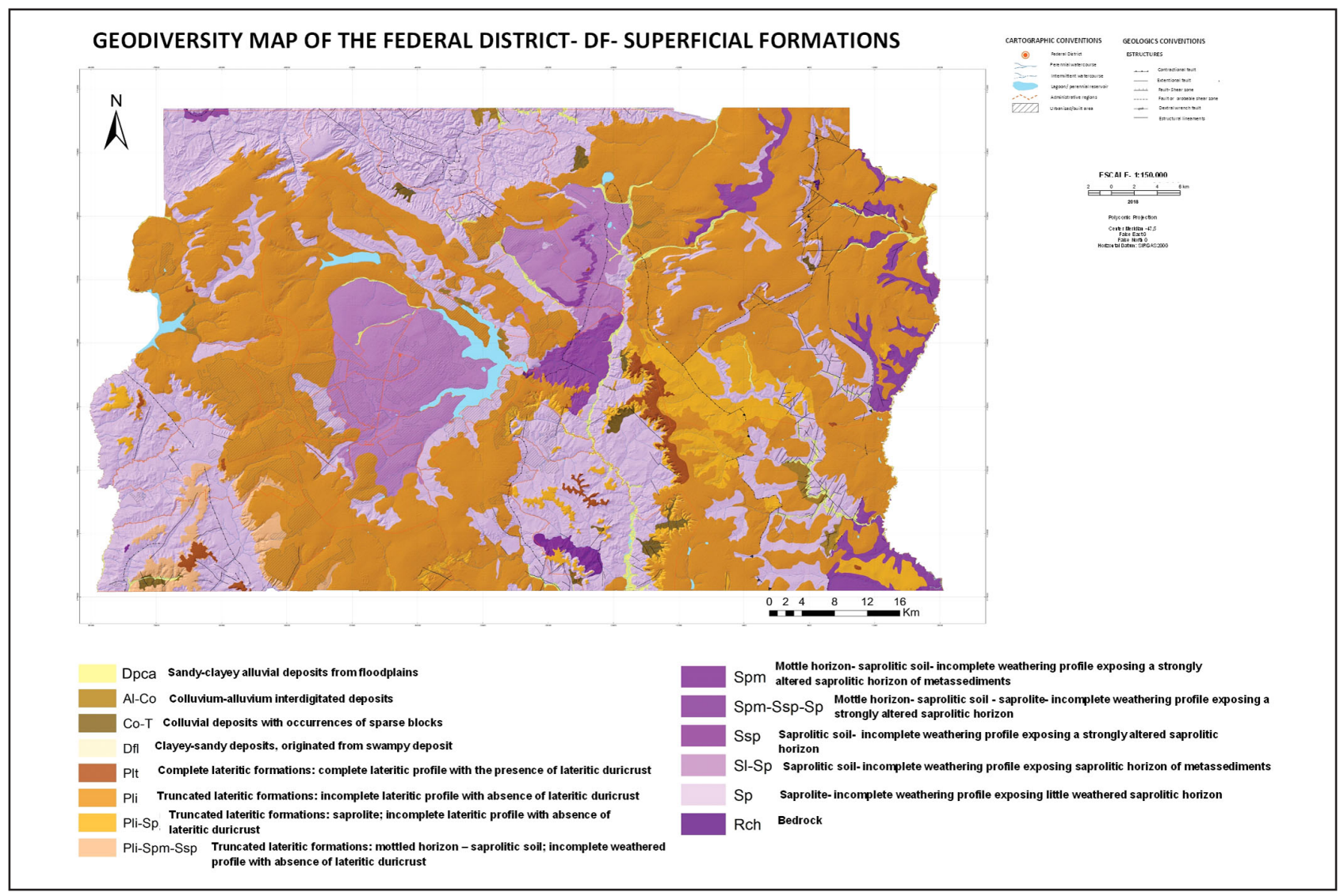

FIGURE 10. Map of superficial formations of the Federal District of Brazil.
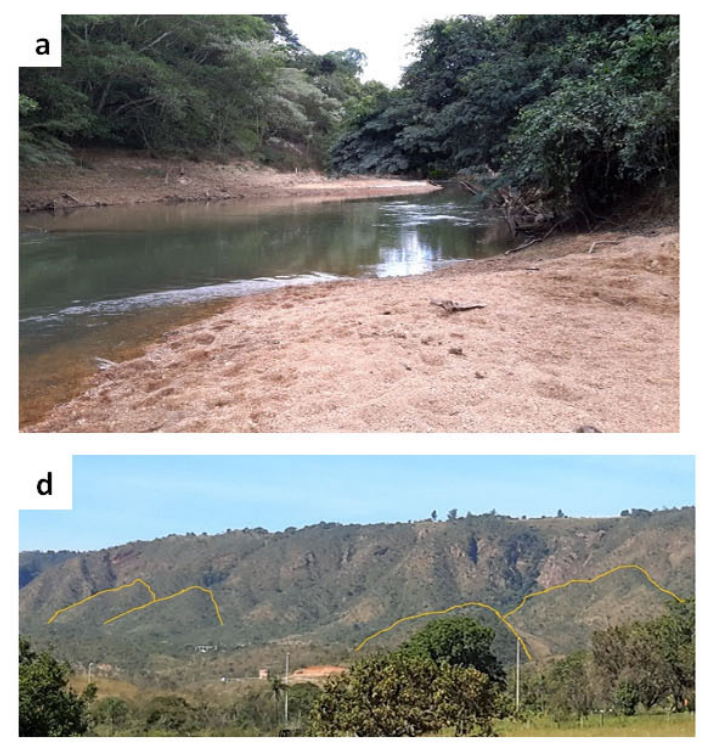
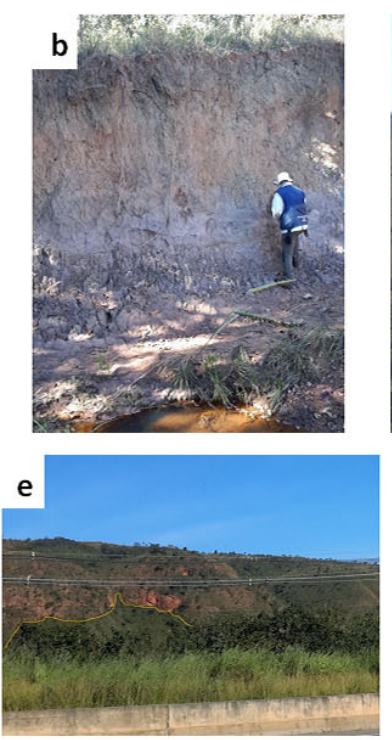

C
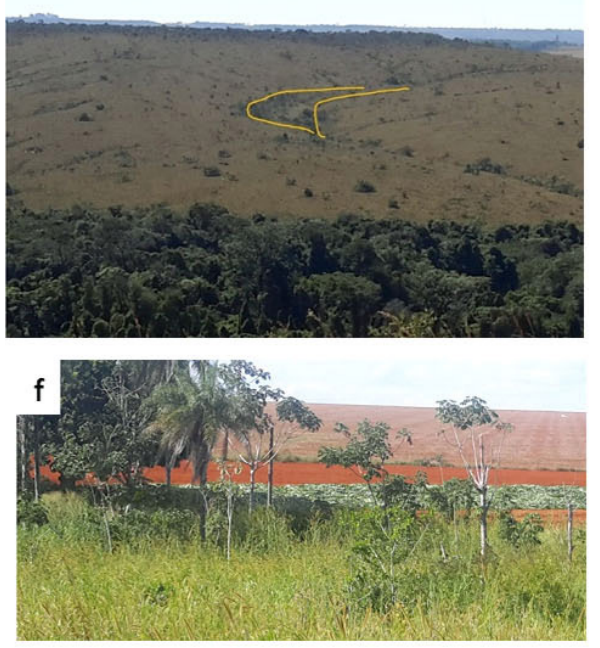

FIGURE 11. a) Sandy alluvial deposits along the São Bartolomeu river. b) Sand-clay sedimentary package, typical of alluvial plains, in a tributary of the Ribeirão Santana creek (São Bartolomeu River Basin), on the access road to Santa Bárbara. c) Detail, in yellow, of the alluvium-colluvium deposit in the São Bartolomeu Basin. Locality of Capão Comprido. d) Colluvium-talus ramps at the foot of the structural step of the central plateau. Locality of Boa Vista. e) Colluvium-talus ramps at the foot of the structural step of the central plateau. f) Brejo (fluvio-lacustrine plain) located in the eastern portion of the Federal District in the Capão Rico creek, Preto river Basin.

\subsubsection{Truncated lateritic formations, with saprolite (Pli-Sp)}

The truncated lateritic formation with a mottled horizon and saprolite soil (Pli-Sp) is found in more heterogeneous reliefs ranging from plateaus and/or flattened surfaces degraded to low hills, passing through degraded escarpments, where the land has slopes ranging from 0 to 25 degrees. Cambisols are the predominant type, along with Ferralsols showing thickness of 0 to $50 \mathrm{~cm}$ and 100 to $200 \mathrm{~cm}$, respectively. Petroplinthic Plinthosols also occur when the pisolitic horizon lies close to the surface. 
The saprolites present in this formation come from alteration of schists and phyllites, locally intercalated with quartz lenses, and pelitic metarythmites, locally with intercalation of quartzites from the Paracatu and Paranoá Formations. Such saprolites are truncated either with Petroplinthic Plinthosols or with Farralsols (Fig. 14).

\subsubsection{Truncated lateritic formations with a mottled} horizon and saprolite soil (Pli-Spm-Ssp)

This lateritic formation contains all the soil and saprolite truncation systems. They are predominantly restricted to plateaus, where the slope varies from 2 to 5 degrees, and

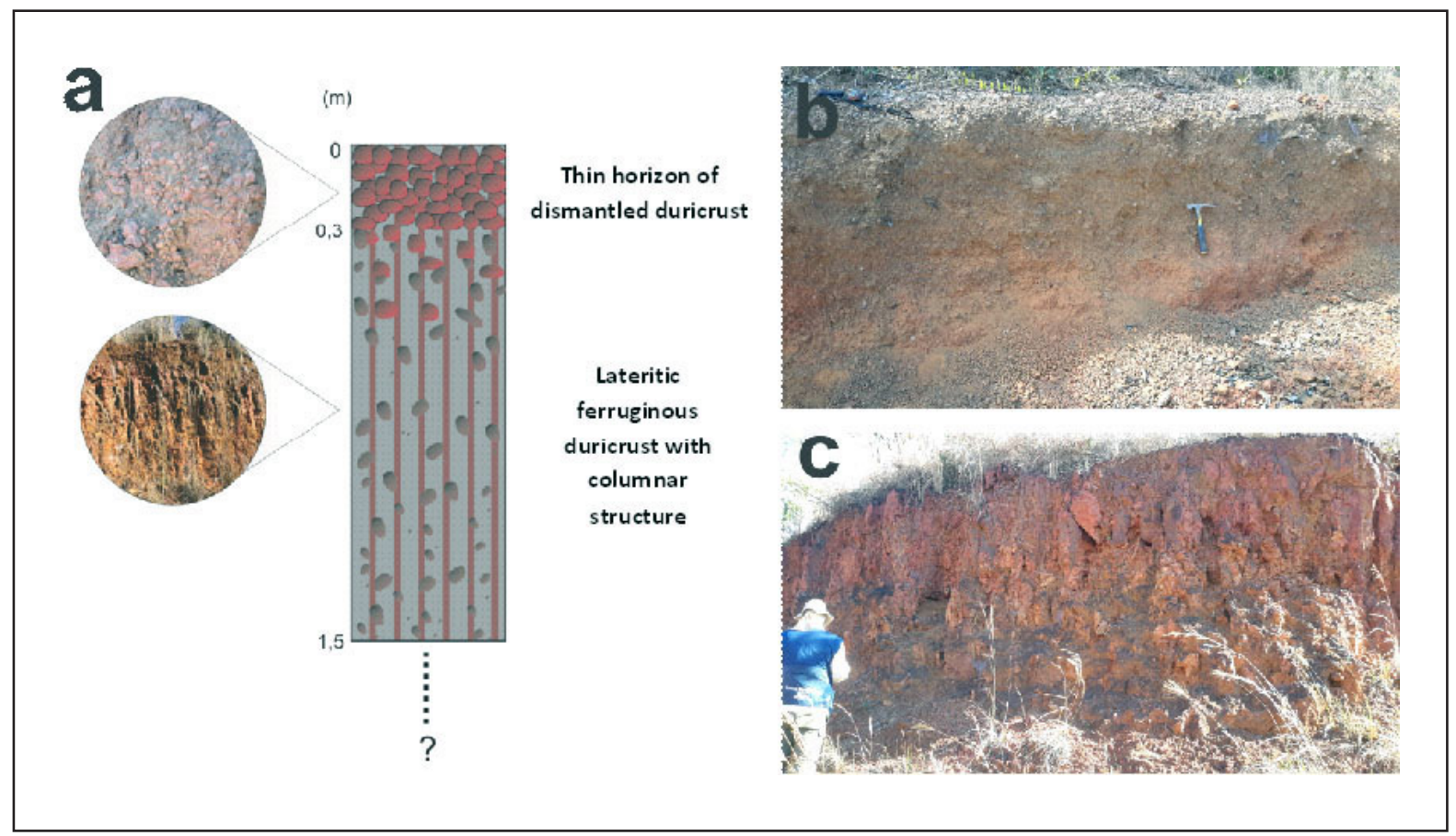

FIGURE 12. a) Complete weathering profile with the presence of lateritic crust (Fernandes et al. 2018), containing lateritic crust overlaid by dismantled crust (DCDL PIt). b) Lateritic crust partially dismantled. Highway DF-100, close to the junction with the DF-105. c) Outcrop of lateritic crust with columnar structure. Highway DF-320.
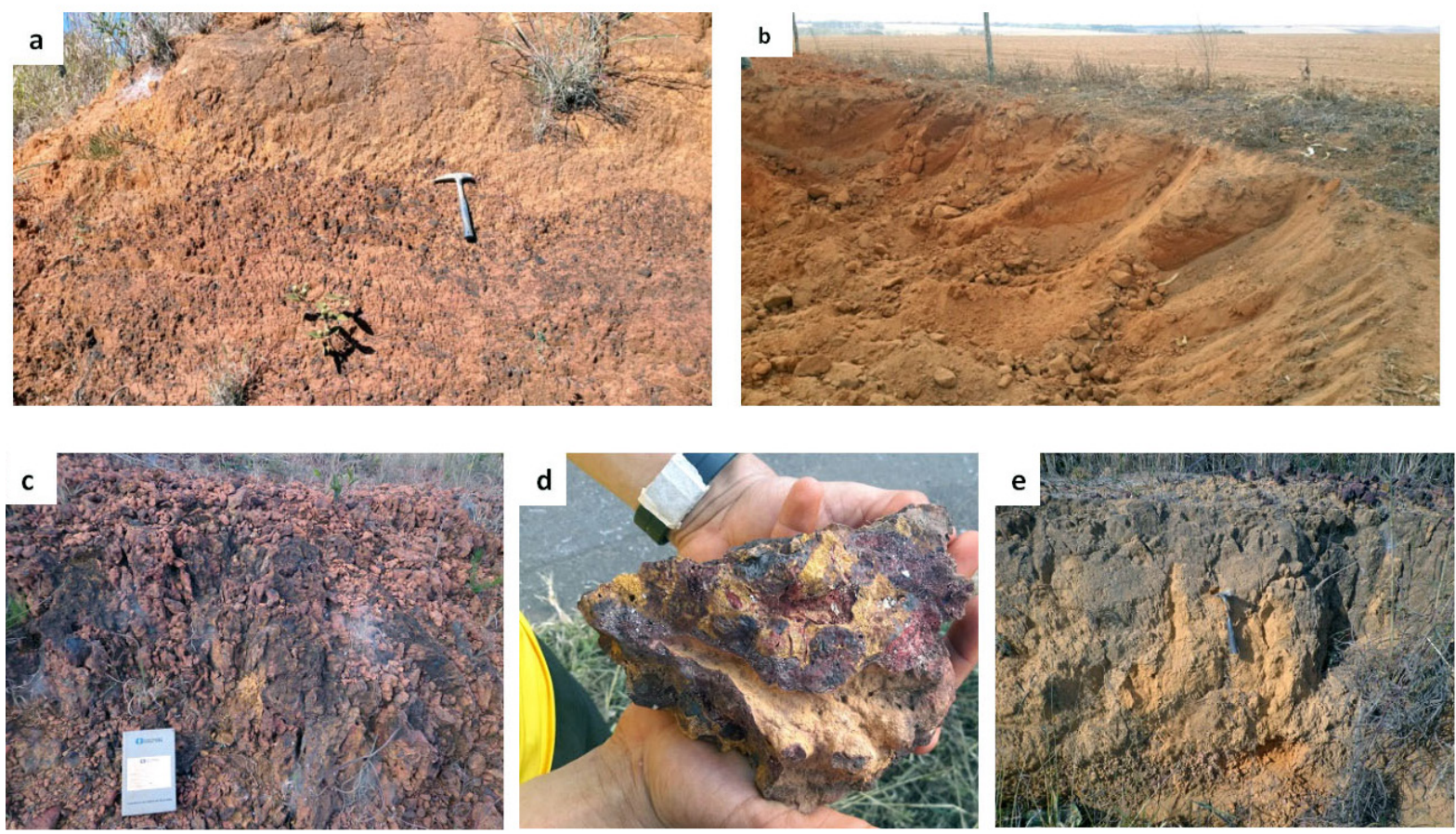

FIGURE 13. a) Ferralsol superimposed on a concretionary horizon. Highway DF-451. b) Excavation exposing a thick layer of Ferralsol over an extensive surface at the top of the plateau. Highway DF-130. c) Outcrop, at the crossroads of the DF-130 highway, with a columnar structure lateritic crust, about 2 meters-thick. d) Detail of the crust structure, overlaid by e) friable pisolitic horizon and yellow soil without structure, just over 1 meter-thick and composed of silt. 


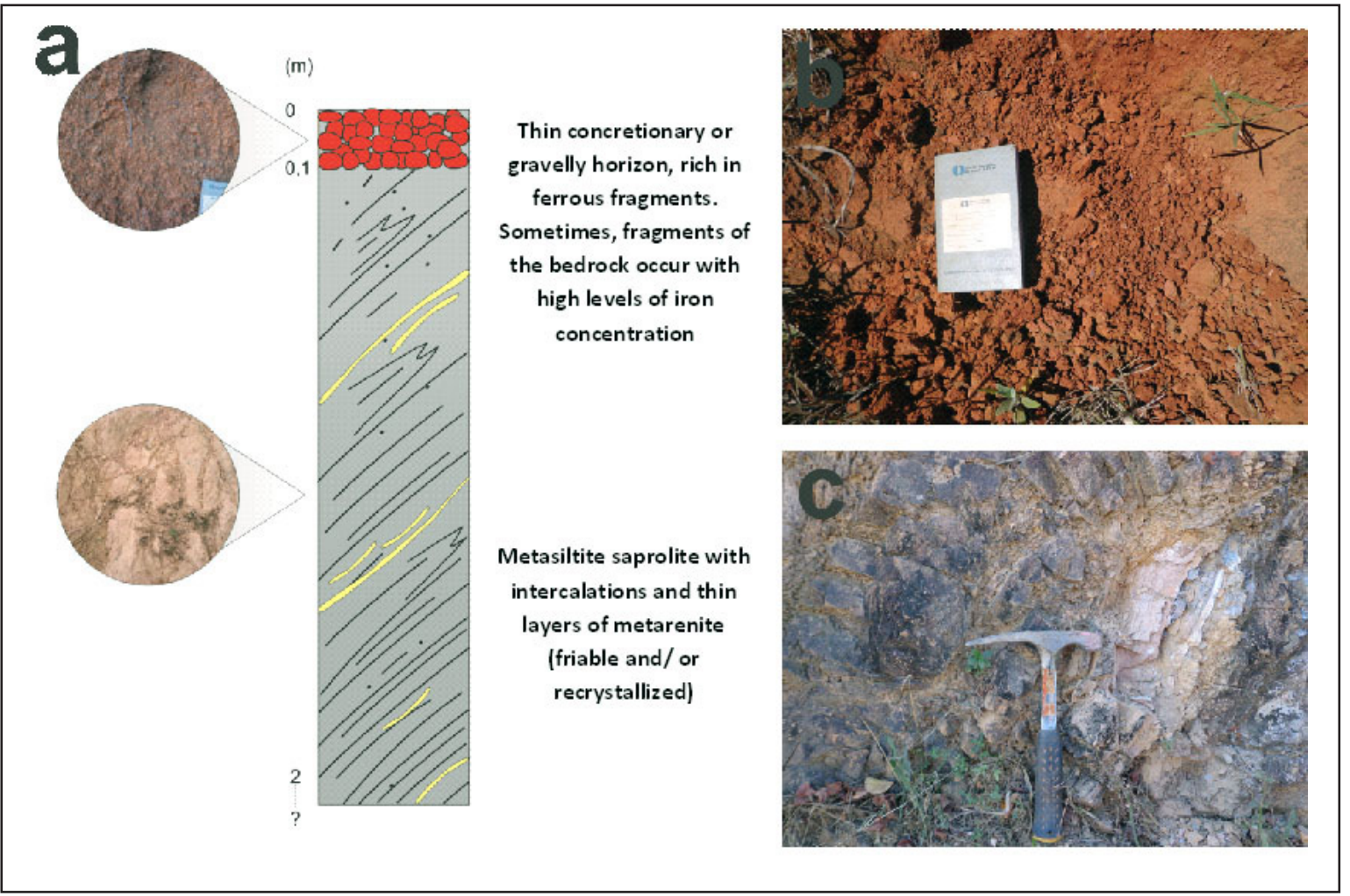

FIGURE 14. a) Petroplinthic Plinthosol superimposed on a saprolite horizon of silt-clay metasediments with subordinate intercalations of sandstones (Pli-Sp). b) Clay soil, with plinthites set in a clay mass, subtly concentrated in the upper portion and rich in relic fragments of stiffened and Fe-rich schist (concretionary) in the lower portion. c) On the relief of low hills crops out a saprolite of weakly altered schist, with centimeter bands of fine metasandstone. The dip of the layers is approximately 45 degrees and there is disaggregation into slabs and blocks.

subordinately to degraded escarpments, structural steps, and erosive edges with a slope of 10 to 25 degrees. There is an incomplete weathering profile, with the occurrence of a lateritic crust dismantled in situ or of allochthonous pisolithic horizons, where Petroplinthic Plinthosols and/or Ferralsols occur over a strongly weathered saprolite horizon derived from alteration of schist and phyllite, locally intercalated with quartz lenses and with a saprolite horizon of pelitic metarythmites, sometimes with quartzite intercalations (Fig. 15).

\subsubsection{Mottled horizon and saprolite soil (Spm-Ssp)}

The mottled horizon and saprolite soil formations occur on plateaus, where the slope varies from 2 to 5 degrees, and on degraded flattened surfaces, with slopes from 0 to 5 degrees. It presents an incomplete weathering profile exposing a mottled horizon superimposed on the horizon of saprolite soil derived from schist and phyllite (Fig. 16a). They are locally intercalated with quartz lenses associated with the weathering of rocks from the Paracatu Formation and the lithofacies Chapada dos Pilões 1 of the Canastra Group. In these terranes predominate Cambisols with thickness varying from 0 to $50 \mathrm{~cm}$.

\subsubsection{Mottled horizon, saprolite, and saprolite soil $(\mathrm{Spm}-\mathrm{Ssp}-\mathrm{Sp}$ )}

This superficial formation is predominant in plateau reliefs, with slopes ranging from 2 to 5 degrees, and escarpments degraded to a lesser extent, which show slopes of 10 to 25 degrees. Cambisols with thickness from 0 to $50 \mathrm{~cm}$ are observed, in addition to incomplete weathering profiles exposing the saprolite soil horizon of metapelites of the Paraopebas Formation (Figs. 16b, 16c, 16d).

\subsubsection{Saprolite soil horizons (SSp)}

The saprolite soil horizons occur in various reliefs of degraded flattened surfaces with a slope of 0 to 5 degrees, plateaus with slopes of 2 to 5 degrees, low hills with slopes of 5 to 20 degrees, and degraded escarpments presenting slopes ranging from 10 to 25 degrees. The soils found in the formation vary from Cambisols to Ferralsols, the latter associated with plateau reliefs. Such soils have a thickness of 0 to $50 \mathrm{~cm}$ and 100 to $200 \mathrm{~cm}$, respectively.

The weathering profile exposes a horizon of saprolite soil of weathered pelitic metarythmites, and also of quartzite, partially underlain by a thin gravel horizon, and peliticcarbonated metarythmites, all belonging to the Paranoá Group 3, and from metasediments that vary from schists to phyllites of the Paracatu Formation, locally intercalated with quartzose lenses (Figs. 16e, 16f).

\subsubsection{Horizons with soil and saprolite (SI-Sp)}

The horizons with soil and saprolite are incomplete weathering profiles exposing quartzite saprolite horizon, in which thick clayey soils rich in quartzite blocks/boulders, and incomplete weathering profile with saprolite horizon of pelitic metarythmites, sometimes with quartzitic intercalations, both belonging to the Paranoá Group. These horizons, in general, 


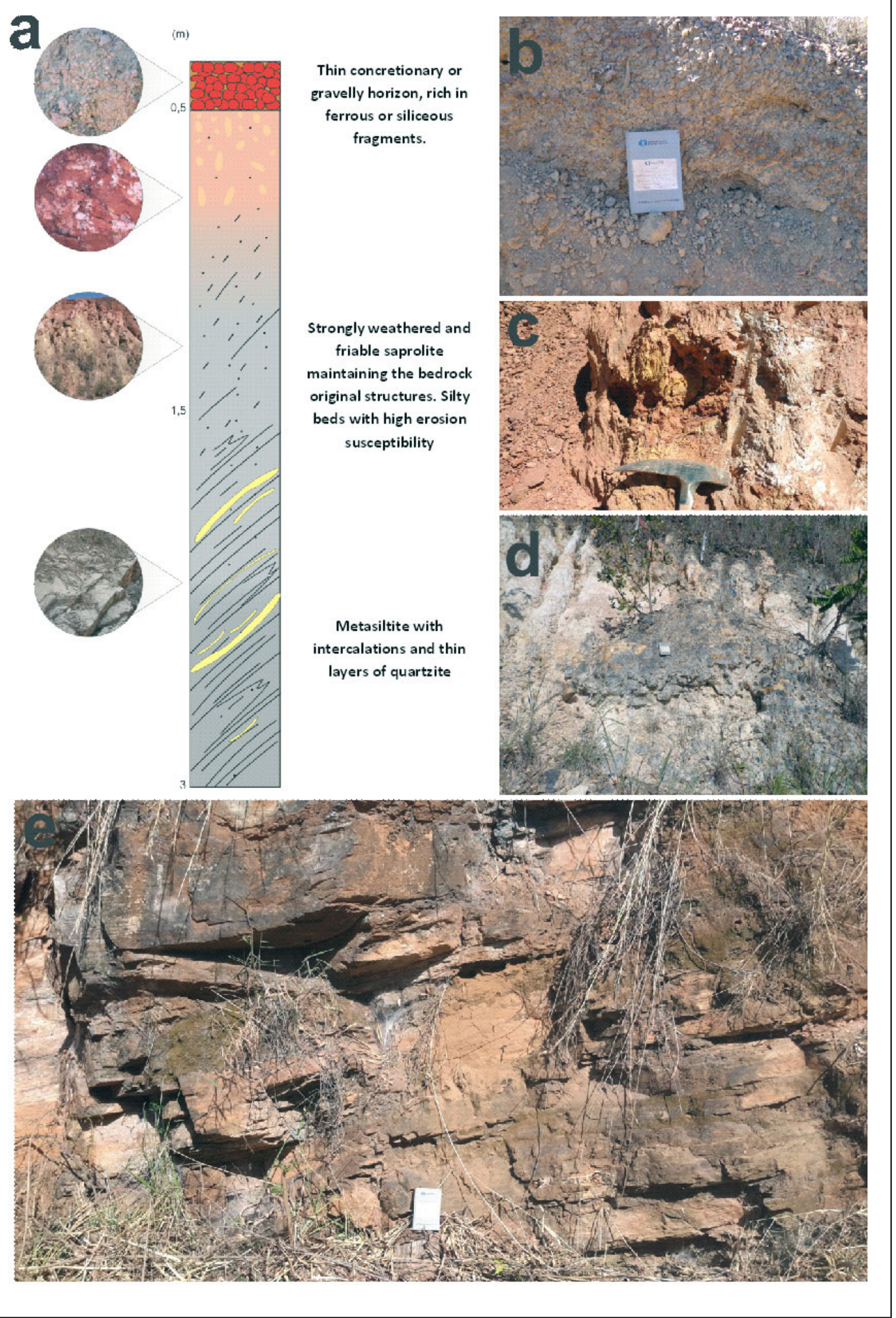

FIGURE 15. a) Petroplinthic Plinthosol superimposed on the mottled and the weakly altered pelitic metarythmite saprolite horizons, sometimes with quartzite intercalations (Pli-Spm -Ssp-Sp). b) Ferruginous concretionary horizon (locally quartzose), between 1 and 1.5 meters thick. Highway DF-473, just after the junction with BR-251. c) Mottled horizon. Highway DF-290. d) Highly eroded road cut, with a strongly altered and friable saprolite of silt and kaolinite metasediment. Intersection of DF-150 with Mato street. e) Outcrop of fine, unaltered and finely foliated metarythmites of the Paranoá Group, light gray in color. Highway DF-205. 

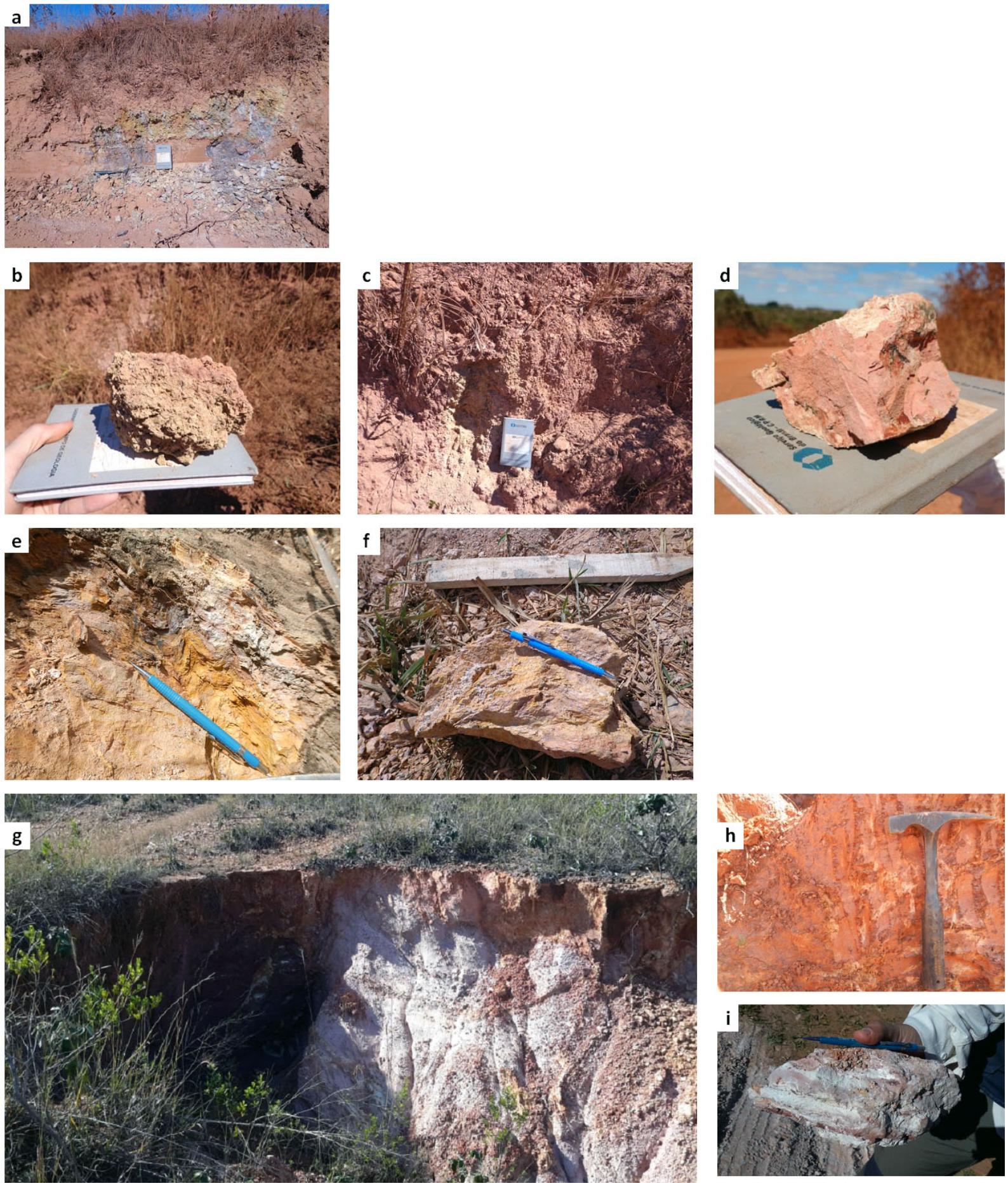

FIGURE 16. a) Road cut with outcrop of saprolite soil derived from graphite schist, under the mottled horizon, which still preserves an incipient structure of the original rock of the Paracatu Formation (Spm-Ssp). Access road to Santa Barbara - Federal District. b) Fragment of the mottled horizon of the strongly altered, clay-rich and silky saprolite. c) Metapelite saprolite soil showing the presence of a degraded crust in situ. d) Very altered saprolite from the metapelite of the Paraopebas Formation. e) Detail of the saprolite soil of a folded and altered silky metasiltstone covered by a layer of quartzite and metasiltstone gravels, both derived from the Paracatu Formation. Highway DF-250. f) Sample of pale yellow saprolite soil derived from very fine-grained silky metasiltstone/schist from the Paracatu Formation. g) Large gully at the edge of the plateau exposing the weathering profile, about 8 meters thick, containing h) discontinuous soil horizon and i) strongly altered saprolite of finely banded metasiltstone of the Paranoá Group.

are found in regions with plateau reliefs and, more strictly, on degraded flattened surfaces, with slopes varying from 0 to 5 degrees. The soils found in the plateau regions and on the degraded flattened surfaces are the Ferralsols and the Cambisols, with thicknesses of 100 to $200 \mathrm{~cm}$ and 0 to $50 \mathrm{~cm}$, respectively (Figs. 16g, 16h, 16i).

\subsubsection{Saprolite horizons (Sp)}

The saprolite horizons comprise incomplete weathering profiles exposing little altered saprolite horizon derived from folded Proterozoic sedimentary rocks, metamorphosed under low to high grade. The altered rocks include schist and 
phyllites of the Paracatu Formation, locally intercalated with quartzose lenses; pelitic-carbonated metarythmites; pelitic metarythmites, sometimes with quartzite intercalations; and quartzite of the Paranoá 3 Formation, partially underlain by thin gravel horizon; limestone; and siltstone from the Paranoá 4 Formation; and siltstone and clay from the Serra da Saudade Formation.

This superficial formation is distributed in several types of reliefs, including plateaus, where they occur overlying Cambisols, with thickness varying from 0 to $100 \mathrm{~cm}$, and
Ferralsols, with thickness from 100 to $200 \mathrm{~cm}$, in lands with slopes of 2 to 5 degrees, and reliefs of high hills to isolated ridges and low mountains, where the altered rocks overly Acrisols and Cambisols, with thicknesses varying from 0 to $100 \mathrm{~cm}$ (Fig. 17).

\section{Final remarks}

The systematic mapping of superficial formations in intertropical regions is of crucial importance for the improvement
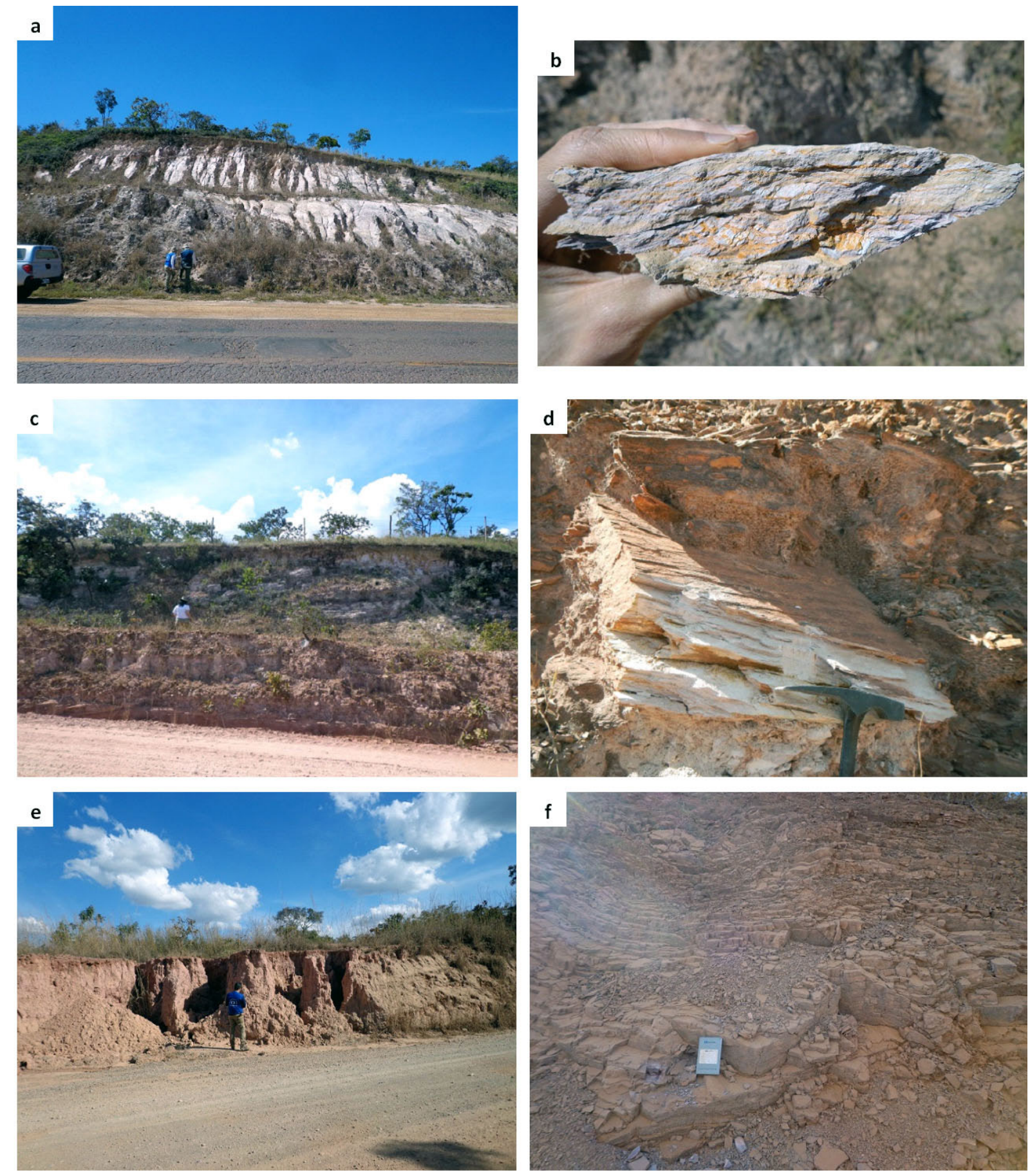

FIGURE 17. a) Road cut about 12 meters high and with many ravines, exposes saprolite of silty phyllite/schist of the Paracatu Formation, which is silky, gray, very altered and easy to excavate. b) Detail of the altered rock. c) Outcrop on light gray to whitish slope of metapelite (phyllite/ schist), rich in sericite, altered and foliated, which disintegrates into plates from the bedrock of the Paracatu Formation. d) Detail for prominent foliation in the altered rock. e) Outcrop of very altered clay saprolite of finely banded metasediment from the Paranoá 4 Formation, composed of hematite, goethite and kaolinite laminae, which is strongly folded and fractured. f). Detail of the prominent foliation in the saprolite (B). 
of geological and geomorphological mappings in semi-detail scales (greater than 1: 100,000) and represents a valuable tool for the multi-thematic analysis of the physical environment applied to land management and assessment of mineral resources. After all, these formations represent weathering profiles, which often reach tens of meters in thickness and present a remarkable internal variability, as demonstrated in this study. As such, the mere mention of the occurrence of the bedrock, underlying a deep and diversified regolith, adds little to the understanding of the local physical environment.

The identification and characterization of the complex geodiversity of a given regolith landscape provides relevant and detailed information for several areas, such as: engineering geology and civil construction; susceptibility to erosion and mass movements; potential for aquifer recharge; mineral potential; etc. Likewise, the mapping of superficial formations provides a more solid and robust base for understanding the geologicalgeomorphological-pedological evolution of a region, in order to recognize its intrinsic weaknesses and provide guidance for more effective projects of environmental management and orderly and sustainable occupation of the territory.

Despite all its importance, very few mappings were produced in Brazil, covering small areas. This stems from a very simple fact: the mapping of superficial formations is very complex and expensive to be carried out systematically over large areas. The methodological proposal presented in this article aims to tackle this challenge by decoding the regolith landscape from a geological-geomorphological-pedological compartmentalization coupled with analysis and description of stratigraphic profiles of the regolith.

The Geological Survey of Brazil - CPRM, through the Geodiversity Project in 2018 and 2019 presented the mapping of superficial formations/regolith of different areas of the North, Northeast, Midwest, and Southeast geographical regions of Brazil. Based on these studies and the results achieved by this paper, which addressed areas with distinct edaphoclimatic characteristics, it was possible to verify that the methodology proposed for the cartography of the superficial formations including the weathering profile is applicable to the entire national territory.

\section{Acknowledgements}

The authors thank Dr. Bruno Martins and the other anonymous reviewers of JGSB for the valuable suggestions, which helped us to improve this article.

\section{References}

Ab'Saber A.N. 1962. Revisão do conhecimento sobre o horizonte superficial de cascalhos inhumados do Brasil Oriental. Boletim Paranaense de Geografia, 2, 1-32.

Alves G.B. 2015. O estudo da cobertura pedológica e sua relação com a formação e evolução de depressões no sudoeste de Maracaí (SP). PhD Thesis, Faculdade de Filosofia, Letras e Ciências Humanas, Departamento de Geografia, Universidade de São Paulo, São Paulo, 201 p. https://doi.org/10.11606/T.8.2014.tde-26052015-095108

Anand R.R., Paine M. 2002. Regolith geology of the Yilgarn Craton, Western Australia: Implications for exploration. Australian Journal of Earth Sciences, 49(1), 3-162. https://doi.org/10.1046/j.14400952.2002.00912.x

Aranha L.G.F., Lima H.P., Souza J.M.P., Makino R.K., Figueiras A.J.M 1990. Origem e evolução das bacias de Bragança-Viseu, São Luís e Ilha Nova. In: Raja Gabaglia G.P., Milani E.J. (eds.). Origem e evolução de bacias sedimentares. Rio de Janeiro, Petrobras, p. 221-233.

Arhin E., Jenkin G.R.T., Cunningham D., Nude O. 2015. Regolith mapping of deeply weathered terrain in savannah regions of the Birimian Lawra Greenstone Belt, Ghana. Journal of Geochemical Exploration, 159, 194-207. https://doi.org/10.1016/j.gexplo.2015.09.008

Azevedo R.P. 1986. Interpretação geodinâmica da evolução mesozóica da Bacia Barreirinhas. In: Congresso Brasileiro de Geologia, 34, 11151130.

Bandeira I.C.N., Barros J.S., Oliveira Filho J.M., Teixeira S.G., Simões P.M.L. 2018. Mapa Geodiversidade da Ilha do Maranhão, Escala 1:80.000. Teresina, CPRM. Available on line at: http://rigeo.cprm.gov. br/jspui/handle/doc/20597/ (accessed on 15 May 2019).

Barbosa O., Braun O.P.G., Dyer R.C., Cunha C.A.B.R. 1970. Geologia da Região do Triângulo Mineiro. Boletim DNPM/DFPM, 136, 1-140.

Bardossy G., Aleva G.J.J. 1990. Lateritic bauxites. Developments in Economic Geology, 27. Elsevier, Amsterdam. 624p.

Birkeland P. W. 1984. Soils and Geomorphology. New York, Oxford University Press, $372 \mathrm{p}$.

Büdel J. 1982. Climatic Geomorphology. Princeton, Princeton University Press, 443p.

Butt C.R.M., Lintern M.J., Anand R.R. 2000. Evolution of regoliths and landscapes in deeply weathered terrain - implications for geochemical exploration. Ore Geology Reviews, 16(3-4), 167-183. https://doi. org/10.1016/S0169-1368(99)00029-3

Butt C.R.M., Zeegers H (eds.). 2015. Regolith exploration geochemistry in Tropical and Subtropical terrains. Handbook of Exploration Geochemistry (4). Amsterdam, Elsevier, 605 p.

Chardon D., Chevillote V., Beauvais A., Grandin G., Boulangé B. 2006. Planation, bauxites and epeirogeny: one or two paleosurfaces on the West African margin? Gemorphology, 82(3-4), 273- 282. https://doi. org/10.1016/j.geomorph.2006.05.008

Chiossi N.J. 1979. Geologia aplicada à Engenharia. São Paulo, Grêmio Politécnico, $428 \mathrm{p}$.

Coelho Netto A.L. 2003. Evolução de Cabeceiras de Drenagem no Médio Vale do Rio Paraíba do Sul (SP/RJ): a Formação e o Crescimento da Rede de Canais sob Controle Estrutural. Revista Brasileira de Geomorfologia, 2, 69-100. http://dx.doi.org/10.20502/rbg.v4i2.25

Coltrinari L. 2011. Paleosurfaces in Southeastern Brazil: São José dos Campos Plateau landform evolution. Geociências, 30(1), 113-120

CPRM - Serviço Geológico Do Brasil, Embrapa. 2003. Zoneamento ecológico-econômico da região integrada de desenvolvimento do Distrito Federal e Entorno: fase I. Rio de Janeiro, CPRM, Embrapa, 3v. Available on line at: http://rigeo.cprm.gov.br/ispui/handle/doc/5044

Craig M.A. 2001. Regolith mapping for geochemical exploration in the Yilgarn Craton, Western Australia. Geochemistry: Exploration, Environment, Analysis, 1 (4): 383-390. https://doi.org/10.1144/ geochem.1.4.383

Costa M.L. 1991. Aspectos geológicos dos lateritos da Amazônia. Revista Brasileira de Geociências, 21(2), 146-160.

Costa M.L. 2007. Introdução ao intemperismo laterítico e à laterização. In: Licht O.A.B., Mello C.S.B., Silva C.R. (eds.). Prospecção geoquímica: depósitos minerais metálicos, não metálicos, óleo e gás. Rio de Janeiro: SBGq, CPRM. p. 199-244.

Dantas M.E., Shinzato E., Bandeira I.C.N., Souza L.V., Renk, J.F.C. 2013. Compartimentação geomorfológica do Estado do Maranhão. In: Bandeira I.C.N. (org.). Geodiversidade do Estado do Maranhão. Teresina: CPRM - Serviço Geológico do Brasil, 31-62. Available on line at: http://rigeo.cprm.gov.br/ispui/handle/doc/14761

Dantas M.E., Shinzato E., Renk J.F.C., Moraes J.M., Machado M.F., Nogueira A.C. 2014. O emprego da geomorfologia para avaliação de suscetibilidade a movimentos de massa e inundação - Mimoso do Sul/ES. Revista Brasileira de Geologia de Engenharia e Ambiental, 4(2), 23-42.

Dewolf Y. 1983. Proposition pour une definition, une tipologie et une cartographie de formations superficieles. São Paulo, USP, Depto. Geografia, 433-445.

Espíndola C.R., Galhego H.R., Garcia G.J. 1981. Desenvolvimento de bacias hidromórficas fechadas em superfícies de latossolos argilosos. Notícia Geomorfológica, 21, 119-131.

Espíndola C.R. 2013. Gênese e evolução das formações superficiais nos trópicos. São Paulo, Editora Beca, $368 \mathrm{p}$

Faria A. 1995. Estratigrafia e sistemas deposicionais do Grupo Paranoá nas áreas de Cristalina, Distrito Federal e São João d'Aliança-Alto Paraiso de Goiás. PhD Thesis, Instituto de Geociências, Universidade de Brasília, Brasília, 199 p. 
Faria A., Dardenne M.A. 1995. Estratigrafia do Grupo Paranoá na região de Alto Paraíso de Goiás-São João D’Aliança - GO. In: Simpósio de Geologia do Centro-Oeste, 5, 75-77.

Fernandes R.L.G., Rocha M.G., Lacerda A.F., Moraes J.M. 2018. Mapa de Geodiversidade do Distrito Federal, Escala 1:100.000. Goiânia: CPRM - Serviço Geológico do Brasil. Available on line at: http://rigeo. cprm.gov.br/ispui/handle/doc/20595 / (accessed on: 20 July 2020).

Filizola H.F., Boulet, R. 1996. Evolution and opening of closed depressions developed in a quartz-kaolinitic sedimentary substratum at Taubaté basin (São Paulo, Brazil) and analogy to the slope evolution. Geomorphology, 16(1), 77-86. https://doi.org/10.1016/0169555X(95)00086-K

Finlayson A.A. 1984. Land surface evaluation for engineering practice: applications of the Australian PUCE system for terrain analysis. Quarterly Journal of Engineering Geology and Hydrogeology, 17(2), 149-158. https://doi.org/10.1144/GSL.QJEG.1984.017.02.06

Ford D., Williams P. 2007. Karst hydrogeology and geomorphology Chichester, J. Wiley \& Sons. https://doi.org/10.1002/9781118684986

Freyssinet P.H., Butt C.R.M., Morris R.C., Piantone P. 2005. Oreforming processes related to lateritic weathering. In: Hedenquist J.W., Thompson J.F.H., Goldfarb R.J., Richards J.P. Economic Geology: One Hundredth Anniversary Volume. Society of Economic Geologists, p. 681-722. https://doi.org/10.5382/AV100.21

Frye J.C., Willman H.B. 1962. Morphostratigraphic units and Pleistocene stratigraphy. AAPG Bulletin, 46(1), 112-113. https://doi.org/10.1306/ BC743763-16BE-11D7-8645000102C1865D

Gibson D.L. 1999. Explanatory notes for the Broken Hill and Curnamona Province 1:500,000 regolith landform maps. CRC LEME open file report, 77.

Góes A.M., Rossetti D.F. 2001. Gênese da Bacia de São Luís-Grajaú. In: Rossetti D.F., Góes A.M., Truckenbrodt W. (eds.). O Cretáceo na Bacia de São-Luís Grajaú. Belém, Museu Paraense Emílio Goeldi, p. 15-19.

Grimaud J.L., Chardon D., Metelka V., Beauvais A., Bamba O 2015. Neogene cratonic erosion fluxes and landform evolution processes from regional regolith mapping (Burkina Faso, West Africa). Geomorphology, 241, 315-330. https://doi.org/10.1016/i geomorph.2015.04.006

Guareschi V., Nummer A. 2014. Depressões fechadas e cabeceiras de drenagem na bacia hidrográfica do arroio Lajeado Taquarembó Planalto Meridional do RS. Revista Geonorte, 5(19), 107-112. Available online at: https://periodicos.ufam.edu.br/index.php/revista-geonorte/ article/view/1467

Guerra A.J.T., Cunha S.B. 1996. Geomorfologia e Meio Ambiente. Rio de Janeiro, Bertrand Brasil, 394 p.

Horbe A.M.C., Nogueira A., Horbe M.A., Costa M.L., Suguio K. 1997. A laterização na gênese das superfícies de aplanamento da região de Presidente Figueiredo - Vila Balbina, nordeste do Amazonas. In: Costa M.L., Angélica, R.S. (orgs.). Contribuições à geologia da Amazônia. Belém, FINEP, SBG-NO. p. 145-176.

Horbe A.M.C., Costa M.L. 2005. Lateritic crusts and related soils in eastern Brazilian Amazonia. Geoderma, 126(3-4), 225-239. https:// doi.org/10.1016/i.geoderma.2004.09.011

IUSS Working Group WRB 2015. World Reference Base for Soil Resources. International soil classification system for naming soils and creating legends for soil maps. World Soil Resources Reports No. 106. FAO, Rome.

Kotschoubey B., Trunckenbrodt W. 1981. Evolução poligenética das bauxitas do distrito de Paragominas-Açailândia (Estados do Pará e Maranhão). Revista Brasileira de Geociências, 11(3), 192-202.

Lima H.P., Aranha L.G.F., Feijó F.J. 1994. Bacias de Bragança, São Luís e Graben de llha Nova. Boletim de Geociências da Petrobras, 8(1), 111-116.

Martins E.S., Reatto A., Carvalho Junior O.A., Guimarães R.F. 2004. Evolução geomorfológica do Distrito Federal. Documentos, 122, 1-57. Available on line at: < http://www.infoteca.cnptia.embrapa.br/bitstream/ doc/569549/1/doc122.pdf>

Millot G. 1983. Planation of Continents by Intertropical Weathering and Pedogenetic Processes. In: International Seminar on Lateritisation Processes, 2, 53-63.

Moura J.R.S., Mello C.L. 1991 Classificação aloestratigráfica do Quaternário superior na região de Bananal (SP/RJ). Revista Brasileira de Geociências, 21(3), 236-254.

Ollier C. 1984. Weathering. London, Longman, 270 p.

Pain C.F., Ollier C.D. 1996. Regolith stratigraphy: principles and problems. AGSO Journal of Australian Geology and Geophysics, 16(3), 197-202.

Pinto M. N. 1987. Superfícies de aplainamento do Distrito Federal. Revista
Brasileira de Geografia. 49(2), 9-26.

Queiroz Neto J.P. 2001. O estudo de formações superficiais no Brasil. Revista do Instituto Geológico, 22(1-2), 65-78.

Queiroz Neto J. P. 2010. O papel da pedogênese no modelado do relevo: busca de novos paradigmas. In: Seminário Latino Americano de Geografia Física, 6, Seminário Ibero-Americano de Geografia Física, 2, 1-19.

Ramos M.A.B., Dantas M.E., Maia M.A.M., Machado M.F., Pfaltzgraff P.A., Ferrassoli M.A., Ferreira C.E.O., Moraes J.M. 2018. Projeto Geodiversidade, Regiões Metropolitanas, Escala 1:100.000: manual técnico. Brasília, CPRM - Serviço Geológico do Brasil, 50p.

Rossetti D.F. 1996. Sequence stratigraphy and depositional evolution of Itapecuru Formation (Late Cretaceous) in the São Luís Basin, northern Brazil. Acta Geologica Leopoldensi, 19, 111-126.

Rossetti D.F. 1997. Facies analysis of the Lower Succession of the Upper Itapecuru Formation, São Luís Basin, northern Brazil. In: Costa M.L., Angélica R.S. (eds). Contribuições à Geologia da Amazônia, Belém, FINEP, SBG-NO. p. 241-284

Rossetti D.F. 2001. Arquitetura deposicional da Bacia de São LuísGrajaú. In: Rossetti D.F., Góes A.M., Truckenbrodt W. (eds.). O Cretáceo na Bacia de São-Luís Grajaú. Belém, Museu Paraense Emílio Goeldi, 31-46.

Rossetti D.F., Truckenbrodt, W. 1997. Classificação estratigráfica para o Albiano-Terciário Inferior (?) na Bacia de São Luís, MA. Boletim do Museu Paraense Emílio Goeldi-Série Ciências da Terra, 9, 31-43.

Rosolen V., Herpin U. 2008. Expansão dos solos hidromórficos e mudanças na paisagem: um estudo de caso na região Sudeste da Amazônia Brasileira. Acta Amazonica, 38(3), 483-490. https://doi. org/10.1590/S0044-59672008000300013

Santos H.G., Jacomine P.K.T., Anjos L.H.C., Oliveira V.A., Lumbreras J.F., Coelho M.R., Almeida J.A., Araujo Filho J.C., Oliveira J.B., Cunha T.J.F. 2018. Sistema Brasileiro de Classificação de Solos. 5 ed, Brasília-DF, Embrapa, 356 p.

Schellmann W. 1983. A new definition of laterite. Geological Survey of India, Memoirs, 120, 1-7.

Schrage T.J., Uagoda, R. 2017. Distribuição espacial de depressões na bacia do alto rio Preto (GO, DF, MG) e suas relações com controles geológicos e pedogeomorfológicos. Revista Brasileira de Geomorfologia, 18(2), 379-395. http://dx.doi.org/10.20502/rbg. v18i2.805

Scislewski G., Frasca A.A.S., Araújo V.A. 2002. Mapa de formações superficiais. In: CPRM - Serviço Geológico Do Brasil, Embrapa. Zoneamento ecológico-econômico da região integrada de desenvolvimento do Distrito Federal e Entorno: fase I. Rio de Janeiro, CPRM, Embrapa, 3v. Available on line at: http://rigeo.cprm.gov.br/ jspui/handle/doc/5044

Scott K.M., Pain C.F. 2008. Regolith Science. Melbourne, CSIRO Publishing, 461p. https://doi.org/10.1071/9780643098268

Soares Junior A.V., Costa J.B.S, Hasui Y. 2008. Evolução da margem atlantica equatorial do Brasil: Três fases distintas. GeocienciasUNESP, 27(4), 427-437.

Souza Filho P.W.M., El-Robrini M. 1997. A Morfologia, Processos de Sedimentação e Litofacies dos Ambientes Morfossedimentares da Planície Costeira Bragantina Nordeste do Estado do Pará (Brasil). Geonomos, 4(2), 1-16.

Szatmari P., Françolin J.B.L., Zanotto O., Wolf S. 1987. Evolução Tectônica da margem equatorial brasileira. Revista Brasileira de Geociências, 17(2), 180-188.

Tardy Y., Nahon D. 1985. Geochemistry of laterites, stability of Al-goethite, $\mathrm{Al}$-hematite, and $\mathrm{Fe}$ 3+-kaolinite in bauxites and ferricretes: an approach to the mechanism of concretion formation. American Journal of Science, 285(10), 865-903. https://doi.org/10.2475/ajs.285.10.865

Teixeira S.G. 2006. Análise de imagens de sensores remotos orbitais para mapeamento de ambientes costeiros tropicais e de índices de sensibilidade ambiental ao derramamento de óleo no Golfão Maranhense. MSc Dissertation, Centro de Geociências, Universidade Federal do Pará, Belém, 171 p. Available on line at: http://rigeo.cprm. gov.br/jspui/handle/doc/182

Thomas M.F. 1994. Geomorphology in the tropics: A study of weathering and denudation in low latitudes. New York, John Willey \& Sons, 460 p. https://doi.org/10.1002/jqs.3390100216

Uagoda R., Avelar A., Coelho Netto A.L. 2011. Karstic morphology control in non-carbonate rocks: Santana basin, middle Paraíba do Sul river valley, Brazil. Zeitschrift für Geomorphologie, 55(1), 1-13. https://doi. org/10.1127/0372-8854/2011/0055-0031

Vasquez M.L., Klein E.L., Lopes E.C.S. 2012. Compartimentação 
Tectônica. In: Klein E.L., Sousa C.S. (orgs). Geologia e recursos minerais do estado do Maranhão: texto explicativo do mapa geológico e de recursos minerais do estado do Maranhão. Escala 1:750.000. Belém, CPRM - Serviço Geológico do Brasil. 150p. Available on line at: http://rigeo.cprm.gov.br/jspui/handle/ doc/17861

Vidal-Torrado P., Ferreira T.O. 2017. Solos de restingas e áreas úmidas costeiras. In: Curi N., Ker, J.C., Novais R.F., Vidal-Torrado P., Schaefer C.E.G.R. Pedologia: solos dos biomas brasileiros. Viçosa, Sociedade Brasileira de Ciência do Solo, 597 p.

Vital S.R. 2015. Análise geológica-geomorfológica das depressões fechadas e dolinas em sedimentos da Formação Barreiras na região de João Pessoa (PB). Tese de Doutorado. Departamento de Geografia, Universidade de Pernambuco, Recife.

Vitte A. C. 2005. Etchplanação dinâmica e episódica nos trópicos quentes e úmidos. Revista do Departamento de Geografia, 16, 105-118. https:// doi.org/10.7154/RDG.2005.0016.0011

Xavier R.A., Coelho Netto A.L. 2014. Caracterização geomorfológica da bacia do Rio Turvo-RJ: médio vale do rio Paraíba do Sul (MVRPS). Revista Brasileira de Geomorfologia, 15(1), 35-45. http://dx.doi.org/10.20502/rbg.v15i1.372 